
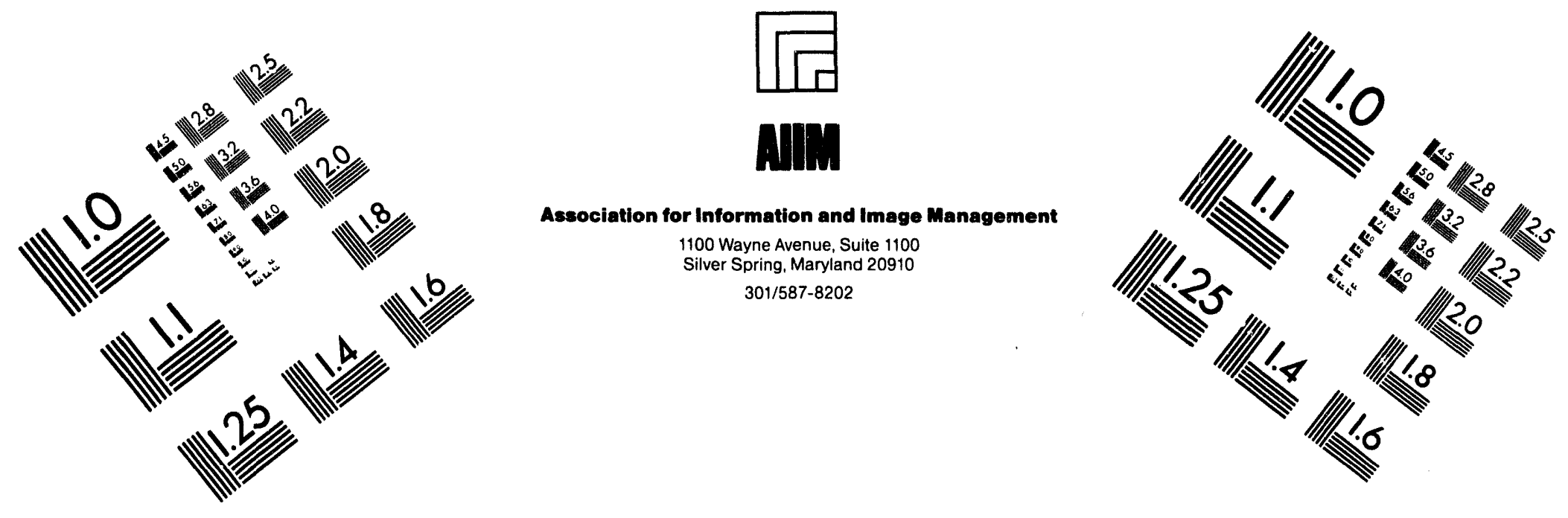

\title{
Centimeter
}

$\begin{array}{llllllllllllllll}1 & 2 & 3 & 4 & 5 & 6 & 7 & 8 & 9 & 10 & 11 & 12 & 13 & 14 & 15 & \mathrm{~mm}\end{array}$

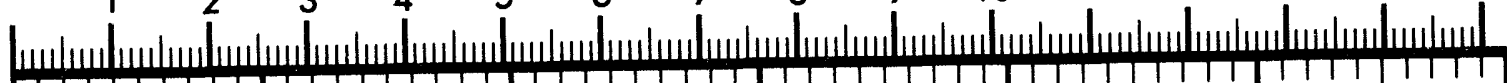

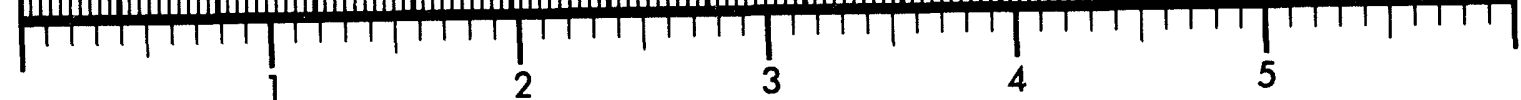
Inches
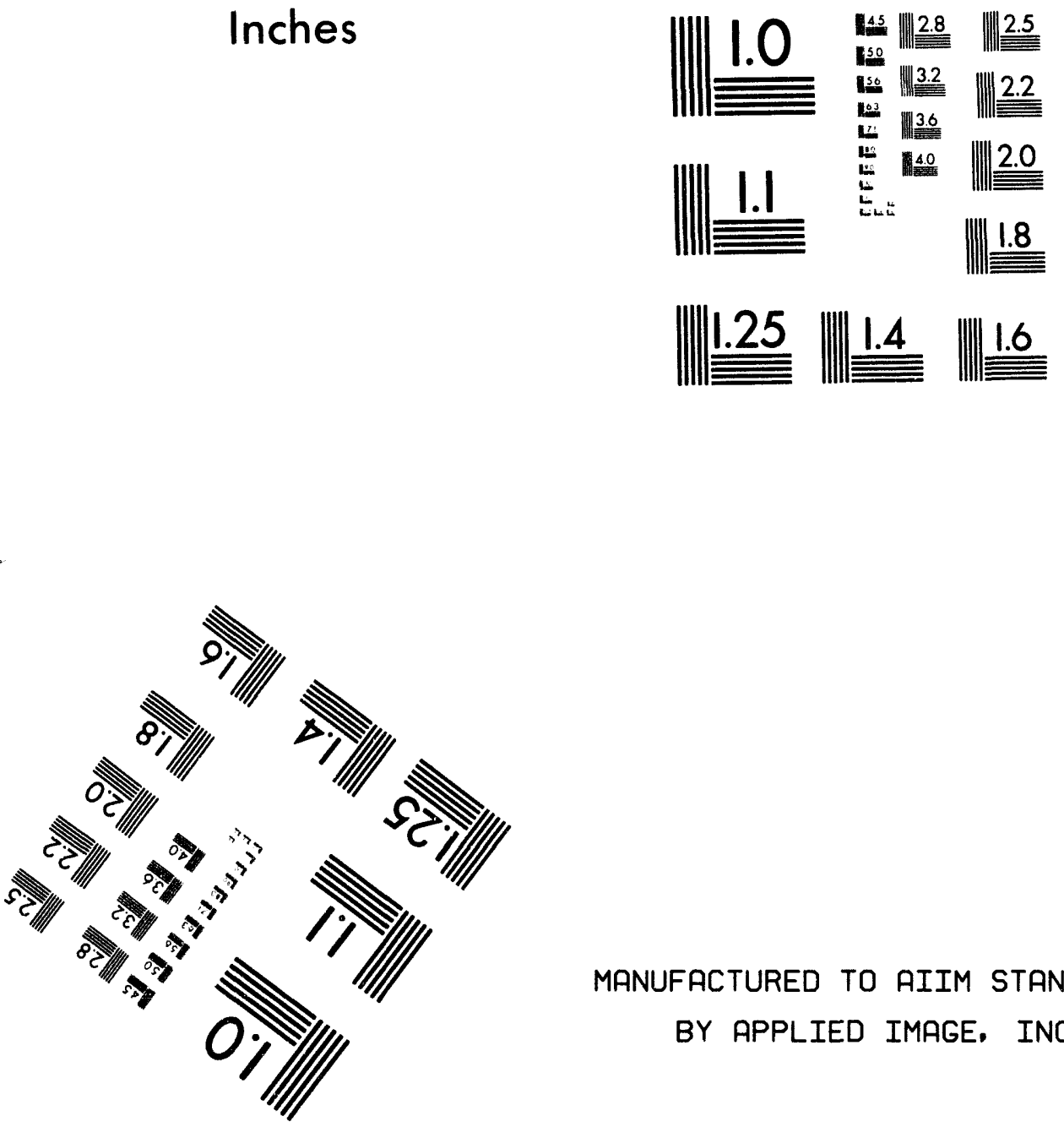

MANUFACTURED TO AIIM STANDARDS

BY APPLIED IMAGE, INC.

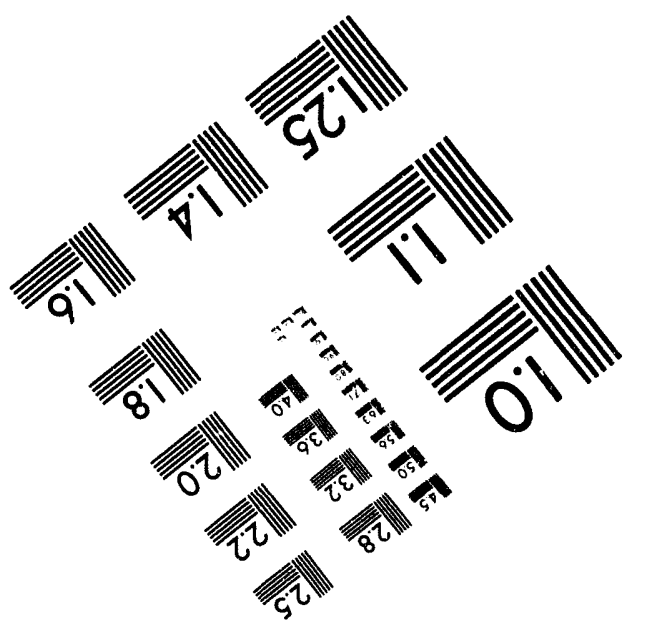



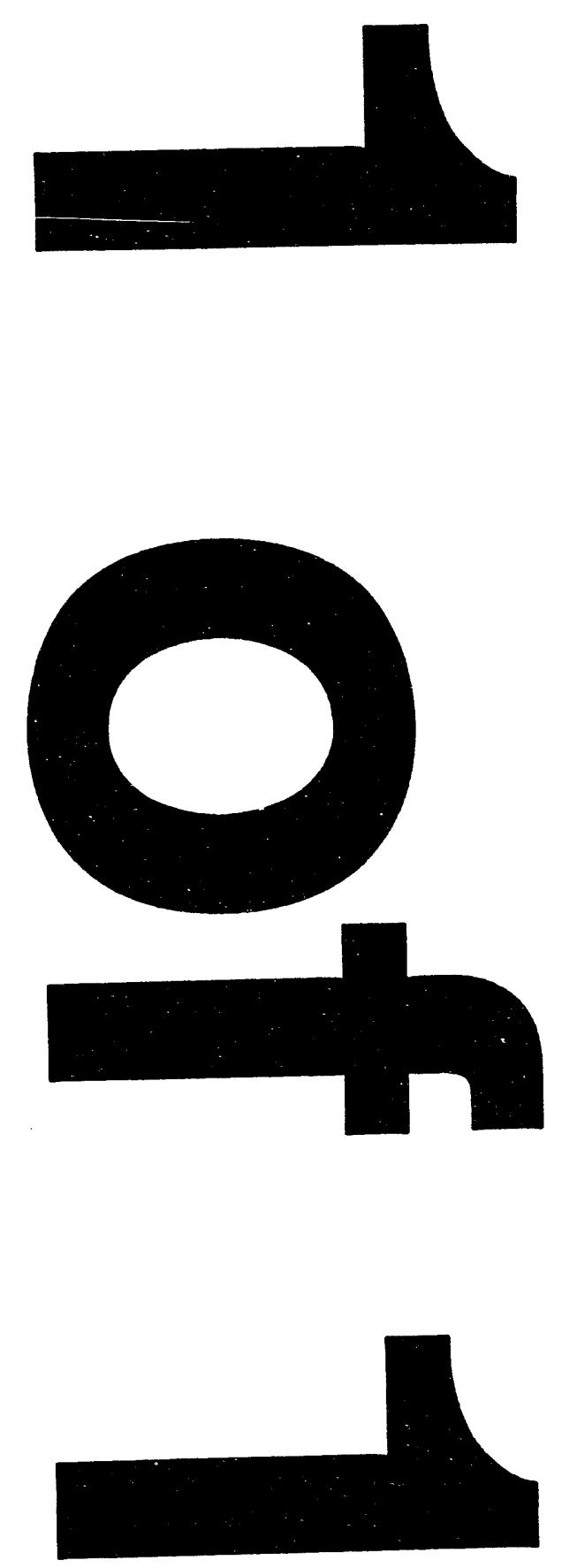


\section{The Reduction of Packaging Waste}

E. A. Raney

J. J. Hogan

M. L. McCollom

R. J. Meyer

Date Published

April 1994

Prepared for the U.S. Department of Energy Office of Environmental Restoration and Waste Management

\footnotetext{
(20) Westinghouse Hanford Company Richland, Washington 99352

Hantord Operations and Engineering Contractor for the

U.S. Department of Energy under Contrect DE-AC06-87RL10930
}
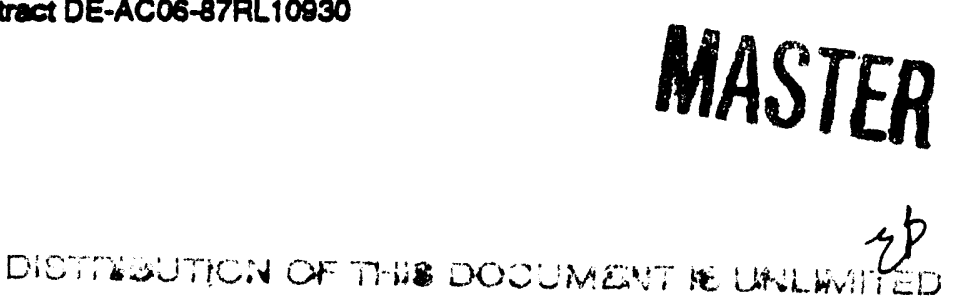

Approved for Public Release 


\section{RELEASE AUTHORIZATION}

Document Numbar: WHC-MR-0448

Document Title: The Reduction of Packaging Waste

Release Date: $\quad 4 / 15 / 94$

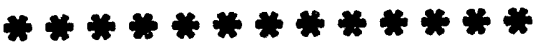

This document was reviewed following the procedures described in WHC-CM-3-4 and is:

\section{APPROVED FOR PUBLIC RELEASE}

$* * * * * * * * * * * * *$

WHC Information Release Administration Specialist:

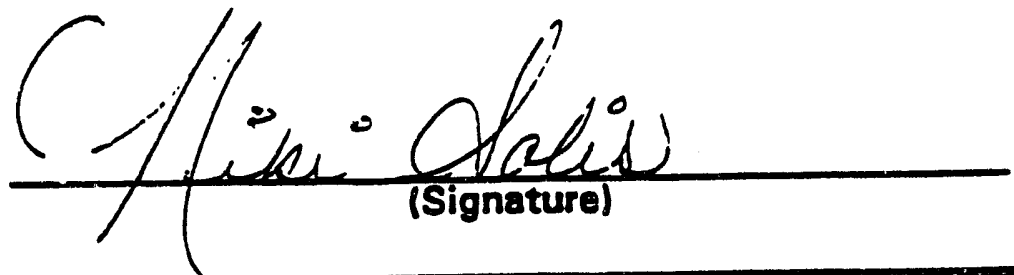


WHC-MR-0448

Document Title:

Prepared by:

Approved by:
The Reduction of Packaging Waste

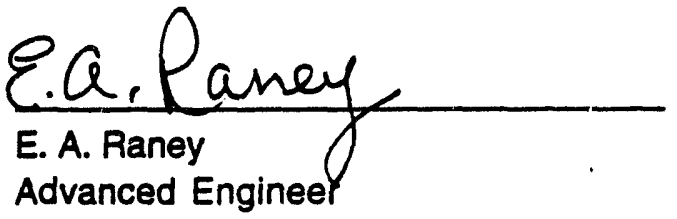

$\frac{4 / 18 / 94}{\text { Date }}$
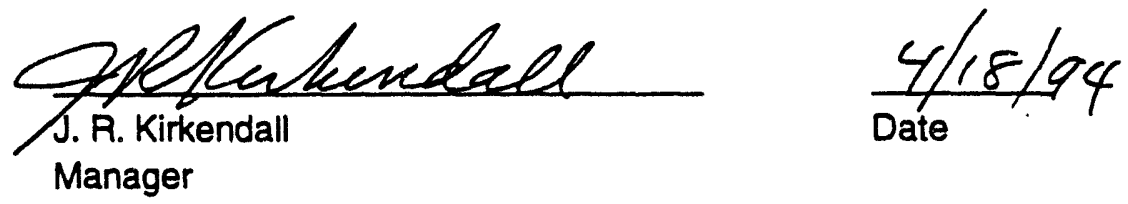

iii 
This page intentionally left blank. 


\section{EXECUTIVE SUMMARY}

Nationwide, packaging waste comprises approximately one-third of the waste disposed in sanitary landfills. In 1992, the U.S. Department of Energy (DOE) generated close to 90,000 metric tons of canitary waste. With roughly one-third of that being packaging waste, approximately 30,000 metric tons are generated per year. The purpose of the Reduction of Packaging Waste project was to investigate opportunities to reduce this packaging waste through source reduction and recycling.

The project was divided into three areas: procurement, onsite packaging and distribution, and recycling. Waste minimization opportunities were identified and investigated within each area, several of which were chosen for further study and small-scale testing at the Hanford Site. Test results were compiled into five "how-to" recipes for implementation at other sites. The subject of the recipes are as follows:

1. Vendor Participation Program

2. Reusable Containers System

3. Shrink-wrap System -- Plastic and Corrugated Cardboard Waste Reduction

4. Cardboard Recycling

5. Wood Recycling.

Based on Hanford Site information, the project also determined a rough baseline of the components and quantities of materials that form the packaging waste stream. Results show that $36 \%$ of the total sanitary waste disposed is packaging waste, and of that quantity, $64 \%$ is corrugated cardboard, $17 \%$ plastic, $8 \%$ wood, $6 \%$ paper packing, and $5 \%$ polystyrene. No single product was found to be a major contributor to the packaging waste stream. Two potential areas for reduction are products that come in standard case lots, and products purchased through a systems contract.

Using information from the U.S. Department of Energy's "Annual Report on Waste Generation and Waste Minimization Progress, 1991-1992" and the "Waste Cost Avoidance Model," (April 1994), a cost savings can be calculated based on an anticipated reduction in sanitary waste. For a $30 \%$ reduction in packaging waste, DOE-wide, an estimated $\$ 6$ million dollars could be saved. 
WHC-MR-0448

$=\quad$ This page intentionally left blank. 
WHC-MR-0448

\section{CONTENTS}

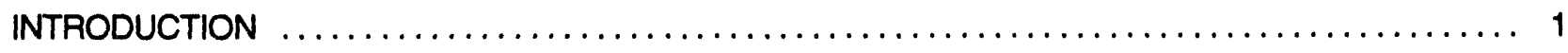

PACKAGING REDUCTION PROJECT--"HOW-TO" RECIPE $\ldots \ldots \ldots \ldots \ldots \ldots \ldots \ldots \ldots \ldots \ldots$

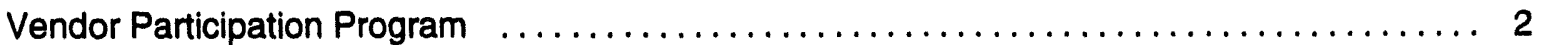

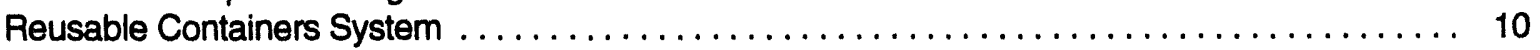

Shrink-wrap System--Plastic and Corrugated Cardboard Waste Reduction $\ldots \ldots \ldots \ldots \ldots \ldots 12$

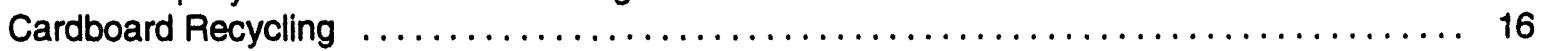

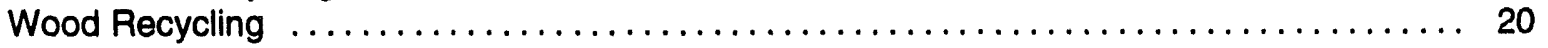

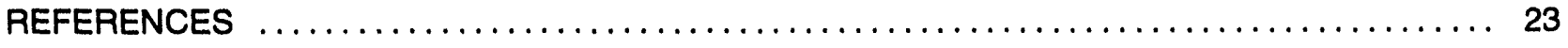

APPENDICES

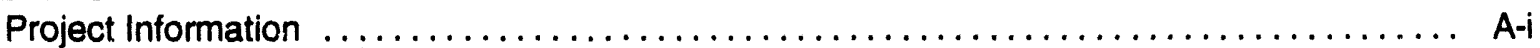

Cost Savings Calculations $\ldots \ldots \ldots \ldots \ldots \ldots \ldots \ldots \ldots \ldots \ldots \ldots \ldots \ldots \ldots \ldots \ldots \ldots \ldots \ldots \ldots \ldots \ldots$ 
WHC-MR-0448

This page intentionally left blank. 


\section{INTRODUCTION}

This document details the fiscal year 1993 activities, results, and recommendations of the Reduction of Packaging Waste Project funded by the U.S. Department of Energy (DOE), Office of Environmental Managment, Waste Minimization Division, (EM-334). The report begins with five "how-to" recipes that were created as standalone documents. Project information and supporting material follow the "how-to" recipes and may be useful for those wishing to investigate packaging reduction at their own facilities.

Following the project information is a short description of how the total cost savings were calculated. The calculations show that within the DOE, approximately 90,000 metric tons of sanitary waste are generated per year. According to national figures and Westinghouse Hanford Company's (WHC) own baselining calculations, more than $30 \%$, or 30,000 metric tons of this is packaging waste. Further, using the preliminary waste cost avoidance model being developed for EM-334, a 30\% DOE-wide reduction in packaging waste would result in an estimated $\$ 6$ million dollars saved.

For a copy of this report or further information, please contact Elizabeth Raney, Westinghouse Hanford Company, Pollution Prevention Program at (509) 372-0469. 


\title{
PACKAGING REDUCTION PROJECT-."HOW-TO" RECIPE
}

\author{
Title: Vendor Participation Program \\ Project Area: Procurement
}

\section{Purpose}

The purpose of the vendor participation program is to establish relationships between purchasers and suppliers io discuss the minimization of packaging waste.

\section{Key Personnel}

Procurement Specialist

Procurement Management

Vendors and Suppliers

\section{Background}

The majority of packaging waste disposed at the Hanford Site landfill is not generated here, but rather is brought onsite by vendors and suppliers who package and ship Hanford Site daily purchases. The general assumption is that the purchaser has no control over this creation of waste. However, large consumers such as the U.S. Department of Energy (DOE) and its contractors are in a good position to form working relationships with their suppliers to discuss packaging reduction needs.

\section{Waste Minimization Opportunity}

The opportunities to reduce packaging waste come from two principal areas. The first is to sensitize the suppliers to DOE's efforts to be environmentally responsible. The second is to allow suppliers to be part of the reduction efforts.

For example, Westinghouse Hanford Company (WHC) has instituted two affirmative procurement clauses (see Attachments $1 \& 2$ ) that support the purchase of environmentally sound products and recycled materials. Vendors have traditionally been wary of reporting recycled content in products because of associations with poor a' ' 'zlity. The affirmative procurement clauses state the importance of environmental stewardship within the D()E community. Communicating these needs to the vendors was important to the process and the respons $\theta$ from the vendors has been favorable.

To encourage suppliers to be part of the reduction efforts, WHC will host a vendor conference or meeting in fiscal year 1994 to encourage affirmative procurement and solicit input and discuss packaging reduction opportunities.

\section{Benefits}

At this point in our efforts, no tangible benefits or cost savings have been measured by WHC; however, there have been a number of intangible benefits. These intangible benefits include such things as receiving some level of buy in or involvement from key suppliers to work on this issue, obtaining suggestions for reducing packaging waste that require further research for implementation, and increasing awareness by both WHC and supplier personnel of the effect affirmative procurement can have on reducing waste generation. 


\section{Cost Savings}

None to report at this time.

\section{How to Implement Activity}

- Identify suppliers who make the majority of deliveries to the Hanford Site. There are two basic types of suppliers: local or distributor-type suppliers who deliver other vendor's products and suppliers that both manufacture and deliver products themselves. Whether a vendor is local or part of a systems contract may affect their involvement as well. A local vendor will deliver in smaller, single-product loads at infrequent time intervals. A systems contract is usually established with a large distributor who acts as a single point of contact for a specinic product area such as office or electrical supplies. This distributor may receive products from many different suppliers which are shipped all at one time, usually in large loads, at very frequent intervals. With a systems contract there is less control over the products that you receive unless the original contract specifies a company's preference for recycled materials, recyclable materials, and reduced packaging.

- Prepare a letter with a questionnaire (see Attachment 3) and send it to the suppliers identified above. This communicates the purpose and mutual objective of reducing packaging waste and solicits their input and involvement in those efforts.

Collect and review the responses from the following perspectives:

- What areas of packaging can be reduced through a cooperative definition of requirements and needs?

- What specific suggestions were offered by the various suppliers and manufacturers?

- Obtain a feel for the level of recycled material now used to package materials and encourage an appropriate level for all similar suppliers.

- Are vendors interested in participating in pallet exchange programs or the return of pallets during backhaul?

- Would vendors be willing to accept return and/or reuse of packaging material?

- Are the vendors interested in participating in a workshop to identify waste minimization opportunities.

- Implement those opportunities identified that are possible. Additional meetings or conversations with vendors may be needed to clarify information and receive their participation and agreement.

- Identify the specific level of recycled material content in all packaging material to be used. Work with the vendors to identify their limitations and concerns. Benchmark other industry standards and agreements for recycled content in packaging.

- Organize and conduct a workshop with interested suppliers and manufacturers to develop additional opportunities to reduce packaging waste.

Questions regarding the implementation or success of this program may be directed to R. J. Meyer, Deputy Manager, Procurement, Westinghouse Hanford Company at (509) 376-3320. 
Attachment 1

\section{AfFirmative PROCUREMENT ClAUSe General Company Statement}

Instructions for clause $(\mathbf{A}-1$, rev. 0$)$

Use: Include in all WHC solicitations that result in any materials being provided to the Hanford Site.

A-1 Recovered material/recyciable information:

Westinghouse Hanford Company (WHC) supports efforts that promoic wsi-ufizuilive icsociiue conservation, recovery, and reuse. Toward that end, the acquisition cycle is viewed as an inportant key in understanding what is brought onto the Hanford Site as well as identifying what can be reused/recycled.

For each end product proposed to be supplied to WHC under a resultant purchase order, information as to the percent of recycled/recovered material incorporated into the end product, as well as possible recycling opportunities shall be provided as set forth below:(use additional pages as necessary for additional items.)

Item No.

$\%$ Recycled/

recovered material

Recyclable

(YN) 
Attachment 2

\section{affirmative procurement Clause Recycled Content Specification}

Minimum recovered content requirement $(A-2$, rev. 0$)$

For the product(s) listed below, the percentage of recovered material listed must be included in the products proposed to Westinghouse Hanford Company (WHC) under this solicitation. Failure to propose products to these minimum levels may be grounds to consider your proposal nonresponsive and not eligible for award. Signature on the face of this solicitation specifically acknowledges compliance with this requirement. It should be noted that in conjunction with any resultant purchase order, WHC may require certifications and/or test results that verify the recovered material content.

A-2 Instructions for clause (A-2, rev. 0)

Use: Include in all WHC solicitations for the paper, insulation, cement, lubricating, or tire products listed. Include the specific product required with the associated percentage of recoverable material per the following table:

Custom clause A-2: Use A-2 to supply the applicable "product" and "percentage of recovered material." Format the clause as shown below, including headings.

\section{Product percentage recovered material}

(A) Paper products

Newsprint

Offset printing paper 50

Mimeo/duplicator paper

Writing paper

Office paper

Envelopes

Book paper

Bond paper

Ledger paper

Cover stock

Toilet tissue

Paper towels

Paper napkins

Facial tissue

Paper dollies

Corrugated pkg boxes

Fiber packaging boxes

Paperboard cartons

Paperboard pad backing

(B) Insulation products

40

Cellulose loose-fill

Cellulose spray-on

Perlite composition board

Rock wool

Phenolic rigid foam

Glass fiber

Foam in place

Rigid form products

(C) Cement and cement products

Product content of fly ash

(D) Lubricating oils

Product content of re-refined

(E) Tires

Must first consider retreads for all applications.
35

80

90

5

5




\section{PACKAGING REDUCTION PROJECT--"HOW-TO" RECIPE Sample Supplier Letter}

Westinghouse Hanford Company (WHC) defines a quality supplier as one that--

- Provides the right materials or services

- Delivers or performs on time

- Provides competitive pricing

- Responds to emergency situations

- Identifies and pursues joint improvemunt opportunities.

Today, one of the most challenging and complex responsibilities we share is the national concern for improvement of our environment and preservation of our natural resourses. A recent study at the Hanford Site parallels those done on a national scale. This study indicates that product packaging is one of the single largest identifiable components of commercial solid waste disposed of in our landfills.

WHC is working to develop innovative, cost-effective alternatives to today's traditional product packaging methods. Specifically, WHC is looking for the following:

- Opportunities to eliminate or minimize by volume and mass the packaging materials used on products shipped to WHC

- Opportunities to incorporate the use of reusable and refillable packaging

- Packaging material that uses increasing amounts of recycled materials

- Opportunities to use packaging that is recyclable.

We recognize that this must be a joint effort. Please complete the enclosed questionnaire and return it within 30 days. We welcome the opportunity to work with you to develop packaging alternatives that are mutually beneficial, both economically and environmentally.

Thank you for your support.

Enclosure: Questionnaire 


\section{Packaging Questionnaire}

\section{Packaging Elimination, Reduction, and Reuse}

1. Can the package used to ship the product be eliminated?

2. If the package itself cannot be eliminated, can the packaging be minimized through:

- Product design changes?

- Packaging design changes?

- Elimination of secondary packaging or wrapping?

- Decreasing the size of the packaging?

3. Can the package be made so that it is eliminated during use of the product?

4. Can the package be made retumable for reuse and redistribution?

5. Do you run a customer packaging return program?

\section{Packaging Recyclability}

6. Is your packaging material recyclable?

7. If yes to question 6 :

- In total, what percent of content consists of recycled material?

- What percent of this is post consumer material?

- Can these percentages be reasonably increased?

8. If no to question 6 :

- Do WHC requirements prevent recyclable packaging?

- Do manufacturer requirements prevent recyclable packaging?

9. Do you currently recycle packaging material?

\section{General}

10. Are you willing to participate in a workshop session with WHC and other suppliers to develop alternative opportunities?

11. Who would you recommend WHC contact to pursue additional altemative opportunities:

12. Comments: 


\title{
PACKAGING REDUCTION PROJECT--"HOW-TO" RECIPE
}

\author{
Title: Reusable Containers System \\ Project Area: Onsite Packaging And Disbursing
}

\section{Purpose}

Conduct a small-scale test to evaluate the use of plastic totes for repackaging and shipping specific store stock items to a selected field location customer. The primary intent is to reduce the amount of corrugated cardboard boxes being shipped to the field. Cardboard boxes captured at Central Stores can be readily iecycier, winich wili recluce the volume of packaging waste being sent to the landfill.

\section{Key Personnel}

Manager, Recycle Programs

Material Specialist, Recycle Programs

Specialists, General Supplies Inventory Control

Manager, Central Stores and Shift Management, Disbursing

Storekeepers and Delivery Truck Drivers

Select Customers and Supervision in the field

Buyer, Procurement

\section{Background}

Store orders for general store stock items are picked and appropriately packaged for shipment to customers in the field. High-volume items such as xerographic paper, janitorial supplies, disposable protective clothing, laundry items, surgical gloves, and many others are routinely ordered in full case lots and are subsequently shipped to the field in their original corrugated cardboard shipping cartons. Tens of thousands of these cardboard boxes are sent to the landfill annually. Virtually all corrugated cardboard sent to the field eventually becomes landfill waste. Accumulating recyclable cardboard at field locations and arranging for subsequent pickup (which requires radiation monitoring in many cases) and transporting it to a centralized staging area is not cost-effective for many facilities or sites.

\section{Waste Minimization Opportunity}

Using plastic totes to ship supplies to the field provides an opportunity for landfill waste volume reduction and resource conservation through recycling. The closed-loop recycling of corrugated cardboard is in line with public sentiment and their environmental expectations from industry.

\section{Benefits}

A substantial landfill cost avoidance can be realized by capturing the corrugated cardboard boxes at Central Stores. Nominal income can be generated through the sale of the recyclable cardboard. Recycling of any kind, once implemented is well received by most employees and produces good morale.

\section{Cost Savings}

The project test of using totes or reusable containers is notably very small scale. Therefore, potential cost benefits were calculated and projected with the assumption that after successful testing full-scale application of the tote system could be implemented. The following data address full-scale implementation. 


\section{Cost Savings (cont.)}

As previously noted, recycling of corrugated cardboard has a dual cost benefit. It produces income (current rate $\$ 37.51 /$ ton) through recycling and affects a disposal cost avoidance $\left(\$ 30.60 / \mathrm{d}^{3}\right.$ ) by keeping a significant portion of packaging waste from requiring landfill disposal. The Hanford Site corrugated cardboard is estimated to comprise $24 \%$ of total landfill waste. Annual baseline total of corrugated cardboard sent to the landfill is $6,542 \mathrm{yd}^{3}$. Using totes would allow a high percentage of corrugated to be recycled. A fully implemnted tote system could capture and recycle an estimated $55 \%$ to $70 \%$ of total corrugated packaging waste. A ton of corrugated is estimated to require $3.9 \mathrm{yd}^{3}$ of landfill space.

\section{Annual potential recycled corrugated cardboard revenue}

$$
\begin{aligned}
& 6,542 \mathrm{yd}^{3} \times 55 \% \text { recovery rate }=3,598.1 \mathrm{yd}^{3} \\
& 3,598.1 \mathrm{yd}^{3} / 3.0 \mathrm{yd} / \text { ton } \quad=922.6 \text { tons } \\
& 922.6 \text { tons recycled } \times \$ 37.51 / \text { ton of cardboard } \quad=\$ 34,607
\end{aligned}
$$

Annual potential landfill cost p" pidance

$$
3,598.1 \mathrm{yd}^{3} \times \$ 30.60 / y \mathrm{~d}^{3} \text { landfill rate } \quad=\$ 110,102
$$

The office paper recycling program reduced janitorial workload in many locations which allowed weekly (versus daily) emptying of waste baskets. The tote system's 3,598 $\mathrm{yd}^{3}$ cardboard reduction would further reduce the workload for janitors. Reduced requirements for garbage truck, driver, and dumpster pickup will allow fewer pickups and trips to the landfill. A cardboard waste reduction of $3,598 \mathrm{yd}^{3}$ is a $13.3 \%$ reduction in total annual landfill waste, which amounted to 27,032 yd in 1992.

The reduced janitorial workload is estimated to equate to 2.5 full-time employees (FTE), while the reduced requirements for garbage collection equates to a 0.4 FTEs. Some uncalculated fuel and maintenance savings on fleet equipment are also expected.

Conversely, storekeeper workload would increase significantly. The number of FTEs required to do the additional work (i.e., unpacking, labeling, and repackaging products into totes) is estimated at 4.0 FTEs.

\begin{tabular}{|c|c|c|}
\hline $\begin{array}{l}\text { Annual labor cost calculations } \\
\text { Janitor chargeout rate/yr }\end{array}$ & $\$ 48,722 \times 2.5 \mathrm{FTE}$ & $=\$ 121,805$ \\
\hline Truck driver chargeout rate/yr & $\$ 57,620 \times 0.4$ FTE & 23,048 \\
\hline Total potential labor cost & avoidance & $=\$ 144,853$ \\
\hline $\begin{array}{l}\text { Storekeeper chargeout rate/yr } \\
\text { Tote return/aggregate rate }\end{array}$ & $\begin{array}{l}\$ 44,561 \times 4.0 \mathrm{FTE} \\
\$ 51,090 \times 0.7 \mathrm{FTE}\end{array}$ & $\begin{array}{l}=\$ 178,244 \\
=\quad 35,763\end{array}$ \\
\hline Total additional labor & & $=\$ 214,007$ \\
\hline Total additional labor & (di & $=\$ 69,154$ \\
\hline
\end{tabular}
The additional truck driver and storekeeper time associated with the pickup and return and handling of empty totes produces an estimated aggregate of 0.7 FTEs per year. Addressing labor aspects, the following determinations were made. 


\section{Cost Savings (cont.)}

The number of totes required to support full-scale implementation of the tote system was estimated to be 1,800. An estimated average cost of $\$ 10.00$ each was established for an initial working stock of a few mixed sizes and types. A $25 \%$ annual replacement factor is expected and is noted below.

Purchase and replacement costs of totes Initial cost of tote $1,800 \times \$ 10.00$ each Replacement factor $\$ 18,000 \times 25 \% / \mathrm{yr}$

$$
\begin{aligned}
& =\$ 18,000 \\
& =\quad 4,500 \\
& =\$ \mathbf{2 2}, \mathbf{5 0 0}
\end{aligned}
$$

Total additional purchase costs

\section{SUMMARY OF ASSOCIATED COSTS}

\section{COST AVOIDANCE ESTIMATES TOTALED}

Corrugated cardboard recycle revenue Landfill oisposal savings

Reduced janitorial requirements

Reduced garbage truck driver requirement

Total
$\$ 34,607$

110,102

121,805

23,048

$\$ 289,562$

\section{IMPACTS/IMPLEMENTATION COSTS TOTALED}

Increased storekeeper labor

Tote return and handling

"Initial tote purchase (first year)

Total
$\$ 178,244$

35,763

18.000

$\$ 232,007$

("Subsequent years, $25 \%$ replacement rate at $\$ 4,500 / y r$.)

\section{NET ANNUAL COST SAVINGS (first year) $\$ 57,555$}

\section{How to Implement Activity}

Initial consultations should be held with management and between the Recycle Programs Specialist and the General Supplies Inventory Control group. Inventory Control Specialists can readily identify highvolume items that would be viable candidates for the tote shipping test(s). Once the item(s) has been selected, the tote's type and size must be dete'mined.

At the Hanford Site, polypropylene disposable protective clothing was chosen for the test. The clothing is shipped and received in corrugated cardboard boxes and includes hoods and shoe covers, and lab coats and coveralls that come in various sizes ( 25 per box).

The Plutonium Finishing Plant (PFP), the major user of this type of clothing, and Central Stores supervision, storekeepers, and delivery truck drivers were consulted regarding viability of the test, type and size of tote required, and about security and safety aspects associated with the change in delivery method. 


\section{How to Implement Activity (cont.)}

A suitable shipping tote must be large enough to accommodate all the contents of one box. Although all of the cardboard boxes that the clothing is received in are the same size, the tote volume required for 25 of the largest size coveralls was used as the determining factor for tote size. Because shipments to the field are often made in open flatbed or stretchout trucks, the tote should also have a snap-on/locking lid for product protection and to keep items secure. Brochures and catalogs from tote suppliers were reviewed using this criteria. A quality brand, light-duty, 18-gallon polyethylene tote with a snap-on lid was selected for the job. The acquisition cost for the test totes was $\$ 4.20$ each. Before placing an urder, an 18-gallon sample tote was tested by unpacking a box of 25 of the largest coveralls to confirm the size and adequacy of the desired tote. An order for 100 totes was then placed. The selected tote is both nestabliz and stackable.

Before implementing the tote deliven system test, the start-p date was coordinated with the customer, storekeepers, and delivery drivers.

Store orders from the PFP facility calling for delivery of protective clothing are flagged for repackaging by disbursing for delivery in totes. The clothing is removed from the cardboard shipping boxes and repacked into correctly labeled totes. The labels are laser printed in quantity and in advance and are 2-by-4 inch, self-adhesive, removable, die-cut labels. The empty corrugated cardboard boxes are broken down, stacked, and banded on scrap pal!ets for pickup by the contracted recycler. The totes are delivered to the customer's dock and, when empty, are placed back on the dock for pickup by the regular Stores driver.

\section{Safety}

All safety aspects were addressed and evaluated at Central Stores and in the field prior to implementation of tote deliveries. Some items noted as potential hazards were paper and/or blade cuts while unpacking boxes for repacking into delivery totes and bending, lifting, and twisting when moving boxes and loading totes onto shipping pallets. Promote and encourage general alertness to recognize and deal with any "hidden safety traps" associated with change.

\section{Recommendations}

The small-scale, short-term ( 3 months) recycling and packaging waste reduction test is currently in progress at the Hanford Site. The test results are being tracked and evaluated for effectiveness. Initial indications are favorable for tote system expansion and continuation in specific product, closed-loop controlled applications. Shipping small-to-medium-sized general supply orders in totes will also be considered after evaluating the PFP test.

Questions about this recycling and packaging waste reduction effort may be directed to J. J. Hogan, Packaging Waste Specialist, Westinghouse Hanford Company, Recycle Programs, at (509) 376-2840. 
WHC-MR-0448

\title{
PACKAGING REDUCTION PROJECT--"HOW-TO" RECIPE
}

\author{
Title: Shrink-wrap System--Plastic and Corrugated Cardboard Waste \\ Reduction \\ Project Area: Onsite Packaging and Disbursing
}

\section{Purpose}

This effort involves the use of thinner shrink-wrap to reduce the amount of polyethylene required to wrap and ship items from the Hanford Site Central Stores operations to the field. Additionally, it involves using lightweight paperboard trays ("doughnut boxes") in place of corru juiteut cardtoa:d $t: 2: \Xi ;$, both used to reduce packaging waste volume going to the landfill.

\section{Key Personnel}

Involvement leading up to and affecting project implementation included consultations with the shrinkwrap system manufacturer, the polyethylene manufacturer, and distributor representatives. Also, paper box suppliers, procurement specialists, disbursing supervisors, storekeepers, and truck drivers who make routine deliveries of the packaged items to the field.

\section{Background}

The Central Stores disbursing operation employs a semiautomated Great Lakes shrink-wrap system to wrap and secure store-stock orders as warranted in preparation for shipment to onsite customers. The system uses a high-clarity polyethylene (poly) shrink-wrap sheeting purchased in a 2.0 mil thickness ( 1 mil $=0,0001$ in.), 30 inches in width. The use of 2.0 -mil poly requires shrink-oven tunnel temperatures of 375 to 400 oF. The 2.0-mil thickness is more than adequate in most applications.

The poly shrink-wrap is used in conjunction with corrugated cardboard boxes and trays that provide form for wrapping, shipping, and handling the various sizes and configurations of orders. The disbursing operation reuses small- and medium-sized cardboard boxes that are generated from receiving activities but also must purchase new boxes to supplement these to fill the large number or Stores orders. In any case, it is assumed that most all corrugated material and other wrappings sent to the field ultimately become landfill waste.

\section{Waste Minimization Opportunity}

A plastic waste volume reduction and raw material and energy conservation can be realized by using a thinner-gauge polyethylene material in the shrink-wrap system. A thinner shrink-wrap material allows for operating the system with lower shrink-oven tunnel temperatures. Corrugated cardboard volume reduction and raw material conservation can be achieved by using lighter weight paperboard boxes, sometimes called "doughnut" boxes or trays, in place of the thicker corrugated cardboard boxes.

\section{Benefits}

The thinner-gauge polyethylene wrapping sheet offers the same quality of performance as the thicker sheet, but offers waste volume reduction and raw materials conservation along with providing a materials cost reduction. And although seemingly incidental, there is also landfill space saved proportionate to the percent of polyethylene thickness reduction. 


\section{Benefits (cont.)}

Using thinner shrink-wrap allows for operating the system with lower shrink-oven tunnel temperatures. This affects energy conservation, lower energy costs, and improved working conditions by having a less adverse effect on the ambient temperature inside the warehouse.

Similarly, along with waste volume reduction and raw materials conservation, the use of paperboard "doughnut" boxes and trays also provides for a materials cost reduction. Using doughnut boxes in all suitable applications reduces the number of new corrugated cardboard boxes that would ordinarily have to be purchased. The practice of reusing corrugated cardboard boxes generated from receiving activities would continue as required. All of these paperboard boxes and trays shipped to the fleld are expected to become landfill waste. However, the volume generated will be significantly less than that of thicker cardboard, resulting in reduced landfill disposal costs.

\section{Cost Savings}

\section{Material Cost Reduction}

A $21 \%$ material cost reduction can be realized using the thinner 1.5 -mil polyethylene shrink-wrap versus the 2.0-mil material. The shrink-wrap system uses about 128,000 linear feet annually. The cost of 2.0-mil meicerial is $\$ 18.72$ per 1,000 linear feet, whereas the 1.5-mil material costs $\$ 14.76$ per 1,000 linear feet.
Poly 2.0 mil
$\$ 18.72 \times 128 \mathrm{~K}$
$=\$ 2,396.16$
Poly 1.5 mil
$\$ 14.76 \times 128 \mathrm{~K}$
$=\$ 1,889.28$
Annual material cost savings for poly
$=\$ \mathbf{5 0 6 . 8 8}$

Lightweight doughnut boxes cost $64 \%$ less than corrugated cardboard boxes and in many cases can replace and perform as well as cardboard boxes. The shrink-wrap packaging line uses about 10,080 smaller-sized corrugated cardboard boxes per year (40/day $\times 252$ workdays/yr). The average cost is $\$ 0.39$ each. Appropriate use of the lightweight doughnut boxes will reduce this usage by at least one-half to 5,040 . The comparative cost of a doughnut box is $\$ 0.14$ each, which is $\$ 0.25$ less per unit.
Cardboard boxes
$\$ 0.39 \times 10,080$
$=\$ 3,931.20$
Doughnut boxes
$\$ 0.14 \times 5,040$
$=\quad 705.60$
Annual material cost savings
$=\$ 3.225 .60$

\section{Landfill Disposal Cost Savings}

Doughnut boxes generate significantly less packaging waste than corrugated cardboard boxes: $50 \%$ less by weight, $75 \%$ less by volume. The typical weight of a cardboard box is 5.6 ounces. A paperboard doughnut box weighs 2.8 ounces. The volume differential is based on surface area and thickness of boxes.

Using doughnut boxes at the shrink-wrap operation is expected to reduce landfilling an estimated $40.0 \mathrm{yd}^{3}$ per year. Using the thinner shrink-wrap will also save up to $6 \mathrm{yd}^{3}$ of landfill space per year. Landfilling cost per cubic yard of waste is currently $\$ 30.60$.

$$
\text { Landfill cost savings/yr } \$ \$ 30.60 \times 46.0 \quad=\$ 1.407 .60
$$


WHC-MR-0448

\title{
Cost Savings (cont.)
}

\section{Energy Conservation Savings}

Energy savings are based on the shrink-wrap oven operating at an average $11 \%$ lower temperature. Before adjusting to lower temperature settings, the oven was consuming an average of 27,000 kilowatt-hours $(\mathrm{kWh})$ per year at the regional rate of $\$ 0.04 / \mathrm{kWh}$.

Energy savings/yr $\quad 27,000 \times \$ 0.04 \times 0.11=\$ 118.80$

\section{TOTAL MATERIAL, LANDFILL, AND ENERGY SAVINGS PER YEAR ESTIMATED AT $=\$ 5.259$}

\begin{abstract}
How to Implement Activity
Consulting with in-house systems maintenance people and/or the shrink-wrap system manufacturer is recommended to confirm whether thinner polyethylene shrink-wrap sheeting would be compatible with existing equipment. Present the fundamentals of the waste minimization opportunity to appropriate management. Obtain their endorsement and follow up with discussions with involved storekeepers and delivery truck drivers, seeking their input and understanding of the waște minimization effort.
\end{abstract}

Contact poly shrink-wrap and paper box vendors for catalogs or product line brochures. Request samples of several thicknesses of shrink-wrap material and a few selected chipboard and/or clay-coated nev/sback board (CCNB) trays and/or boxes for preliminary small-scale performance testing.

At the Hanford Site, initial small-scale tests of thinner-gauge polyethylene sheeting were conducted on the Central Stores Great Lakes shrink-wrap system. Results were favorable for a possible change over from 2.0-mil to 1.5-mil material.

Expanded testing involved using progressively thinner polyethylene in the wrapping and packaging process to a point where it became obvious that the test material was too thin to provide packaging integrity. Conveyor belt speeds and oven-tunnel temperatures were adjusted as necessary during the tests to achieve optimum shrink-wrap performance.

The thinnest polyethylene tested and which subsequently failed to produce an acceptable package was 1.125-mil (0.00125-in.) material. The most successful results were obtained during the 1.5-mil material testing at a reduced temperature of 340 to 350 of versus the higher temperatures of 375 to 400 oF required when working with the 2.0-mil material. Various combinations of conveyor belt speeds, from 10.6 to 20 rotations per minute (rpm), and travel time through the oven tunnel, from 12 to 18 seconds were evaluated. Optimum performance was found at the 10.6-rpm/18-second setting. This is the same setting routinely used when working with the standard 2.0-mil material, so there was no change in operating procedures with the thinner shrink-wrap material.

The tests were run on small-to-medium-sized orders, typical of those usually sent through the shrink-wrap system. Very satisfactory results were obtained using both chipboard "doughnut" trays measuring 14 by 10 by 3.5 in. and CCNB trays/boxes measuring 11.125 by 8.625 by 2 in. Only occasionally did a package require double shrink-wrapping or taping to ensure safety in handling and package integrity.

Following the successful initial testing, adequate quantities of 1.5-mil shrink-wrap and paperboard trays and boxes were purchased to support an expanded test program. This testing period was originally slated for a minimum 3-month duration. However, early indications are very favorable for continuance. 


\section{Safoty}

Testing and changeover activities were evaluated and conducted with safety in mind. Potential hazards were observed and discussed with personnel. Some items noted were potential pinch and head injury hazards while adjusting conveyor belt speeds. Potential burn hazards exist from testing various oven temperatures, from melted/melting plastic, and from too thin or melted plastic allowing heavier items to fall out of packaging. Stress general alertness to "hidden safety traps" associated with change.

\section{Recommendations}

This program is considered to be a very worthwhile, cost-effective waste reduction effort. Cost avoidance and cost savings are substantial and there is virtually no "out-of-pocket" cost for implementation.

When adapting such a program, care should be taken in final selection of the thinner gauge shrink-wrap. The reason for this is that polyethylene vendors can usually furnish small amounts of sample materials for preliminary tests, whereas, actual production runs usually require a minimum $454 \mathrm{~kg}(1,000-\mathrm{lb})$ order.

At the Hanford Site, this amounted to 22 rolls of 1.5-mil shrink-wrap equal to an approximate 3-month material supply. Conversely, paper box vendors can readily furnish selected samples of chipboard and CCNB trays and boxes and generally there are no minimum quantity problems when placing singular-case or multi-case orders.

Questions about this program may be directed to J. J. Hogan, Packaging Waste Project Specialist, Westinghouse Hanford Company, Recycle Programs, at (509) 376-2840. 


\title{
PACKAGING REDUCTION PROJECT--"HOW-TO" RECIPE
}

\author{
Title: Cardboard Recycling \\ Project Area: Recycling
}

\section{Purpose}

The purpose of this recycling activity is to reduce the quantity of corrugated cardboard packaging waste being sent to the landfill through the establishment of a sitewide recycling program. Cardboard waste at the Hanford Site consists primarily of secondary and tertiary packaging waste such as corrugated boxes ariu the corrugated product dividers found inside these boxes.

\section{Key Personnel}

Manager, Recycle Programs

Material Specialist, Recycle Programs

Manager, Central Stores Receiving

Storekeepers, Materials Management

Truck Drivers, Materials Management

\section{Background}

Cardboard materials were collected on a daily basis and put into the office trash containers for transportation to the Hanford Site Central Landfill. The large volume of cardboard generated at Central Stores alone required the containers to be emptied three times per week. Cardboard boxes were not flattened and therefore occupied an inordinate volume of the containers when compared to the material weight.

\section{Waste Minimization Opportunity}

The opportunity to reduce the volume of cardboard material being sent to the landfill is directly related to the feasibility of the collection process. Cardboard is a product with minimal value and is both awkward and bulky to handle. At the Hanford Site, the vendor that recycles the office paper was contacted regarding a cost-effective collection process. The vendor agreed to take the material after it is collected and pay the going rate for cardboard scrap, but they will not collect it using their labor or capital resources. A similar response was received from other local recycling vendors. For the recycling process to work, the cardboard must be collected by Hanford Site plant forces.

Cardboard is currently collected from the Central Stores warehouse operations, the moving box recycling program, and several site facilities. Future cardboard recycling plans include increasing the number of participating facilities and thereby increasing the total quantity of cardboard recycled to approximately $35 \%$. To increase participation in the cardboard recycle program, cardboard collection drops will be established in outer area warehouse facilities. The pickup and delivery of cardboard from each location will be performed by truck drivers assigned to each of the outer area facilities. The vendor will arrange for pickup and transportation after a sufficient quantity of cardboard is collected. 


\section{Benefits}

The tangible benefits of cardboard recycling can be documented by measuring the reduction of the volume of material put into the landfill. The quantity of cardboard recycled can be multiplied by the current landfill disposal charge per cubic yard of material. The current rate at the Hanford Site landfill is $\$ 30.60$ per cubic yard. The labor cost of collecting the material at Central Stores is at a break even point between putting the material in the waste container and palletizing the material for recycling. Costs for facilities to collect and recycle cardboard are unknown.

Intangible benefits are more difficult to measure, but are easy to observe. Improved morale of the people involved in the recycle activity at the Hanford Site can be observed by the enthusiasm, eagerness, and acceptance that is shown toward the recycle programs already in place. The cardboard program is generating the same level of interest and people continually contact the Recycle Programs Group asking how to join the program and/or help further promote the program's success.

\section{Cost Savings}

The tangible cost benefits of the cardboard recycle program can be calculated by using the landfill disposal cost times the quantity of cardboard recycled. The vendor buying the recycled cardboard pays for the material based upon a percentage of a quoted market price. In 1992, this value was $\$ 37.51$ per ton and 30.6 tons of cardboard were recycled from Central Stores and facility operations generating $\$ 1,148$ in revenue. This value will fluctuate greatly from year to year based on the market demand for recycled cardboard. The 1992 value reflects a low demand for cardboard and a glut in the market. To derive the landfill or disposal costs avoided, the 30.6 (tonnage) is multipligd by $3.9 \mathrm{yd} 3 \mathrm{per}$ ton (density of cardboard waste) ${ }^{1}$ to get the total cubic yards of landfill avoided. Cubic yards are then multiplied by the landfill disposal costs to determine annualized savings. Revenue generated from recycling is added to that to get a net cost benefit received. The cost savings data are outlined below.

The savings from recycling moving boxes have been far greater than expected. In 1992, 13,050 moving boxes with lids were reused. The boxes cost $\$ 0.43$ each and lids cost $\$ 0.19$ each. Every time the box and lid are reused, the cost of a new purchase is avoided. In addition, $146.3 \mathrm{yd}^{3}$ of landfill space were saved at cost of $\$ 30.60$ per cubic yard. The cost savings data are outlined below.

The cardboard recycling program has reduced the cardboard waste stream by $247.3 \mathrm{yd} 3 \mathrm{~s}$ since January 1992. Dividing $247.3 \mathrm{yd}^{3}$ by the baseline of $6,542 \mathrm{yd}^{3}$ shows that a reduction of $3.8 \%$ has already been achieved. (The baseline quantity is the estimated total amount of cardboard generated per year.) As the program grows and more facilities meet the participation criteria, it is estimated that 2,300 $\mathrm{yd}^{3}$ per year can be diverted from the landfill. Dividing 2,300 by 6,542 reveals an estimated reduction of $35 \%$. The cost savings data on this estimated total are provided below.

\section{Outline of Cost Savings}

\section{Cardboard packaging at Central Stores and facilities}

30.6 tons $\times 3.9 \mathrm{yd} 3 /$ ton $=119.34 \mathrm{yd}^{3}$

Revenue from recycling $(30.6 \times \$ 37.51 /$ ton $)$

Landfill costs avoided $\left(119.34 \times \$ 30.60 / \mathrm{yd}^{3}\right)$

$\$ 1,148$

3,652

Actual annualized benefit received 


\section{Outline of Cost Savings (cont.)}

\section{Moving boxes program}

13,050 boxes $/(150$ per/yd3)

$=87.0 \mathrm{yd}^{3}$

$13,050 \mathrm{lids} /\left(220 \mathrm{per}^{\mathrm{y}} \mathrm{d}^{3}\right)$

Total cubic yards

$=59.3 \mathrm{yd}^{3}$

146.3/(3.9 yd3/ton)

$=146.3 \mathrm{yd}^{3}$

$=37.5$ tons

Savings by not purchasing new boxes $(13,050 \times \$ 0.43) \$ 5,612$

Savings by not purchasing new lids $(13,050 \times \$ 0.19) \quad 2,479$

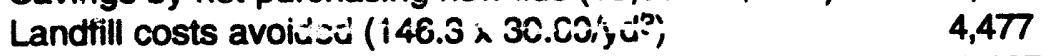

Revenue from recycling (44.3 x \$37.51/ton) 1.407

Actual annualized benefit received $\$ 1 \frac{1,975}{13,975}$

\section{Actual total annualized cost savings $\$ \$ \$ 18,775$}

\section{Estimated future savings}

Landfill costs avoided $\left(2,350 \mathrm{yd}^{3} \times \$ 30.60 / \mathrm{yd}^{3}\right) \quad \$ 70,380$

Revenue from recycling $(2,350 / 3.9=712.1$ tons $\times \$ 37.51)$

Estimated total annualized savings $\$ 92,501$

\section{How to Implement Activity}

First, isolate specific locations that create large volumes of cardboard waste material. The Hanford Site Central Stores operation was selected because all products come through the Central Stores facility before delivery to the Hanford Site. Specific products were then targeted for evaluation of recycling potential. Fumiture was the single largest contributor and became the first test activity. The storekeepers handing the fumiture removed any cardboard packaging, folded it up flat, and stacked it on a pallet. To facilitate safe transportation, the palletized material is banded to the pallet when it reaches a height of about $4 \mathrm{ft}$.

Second, find facilities that have a potential collection point within the facility. Each facility is responsible for scheduling cardboard pickup and return to the Central Stores building. The Central Stores delivery trucks, which are retuming empty following deliveries onsite, are used to transport the collected cardboard to the Central Stores pickup point. Many factors are considered before a facility is added to the program. Radiation monitoring/release and collection concems are the two $m$ jor deterrents to facilities joining the cardboard recycle program at the Hanford Site. Plans include increasing the number of facilities participating. 
How to Implement Activity (cont.)

Another source of recycled cardbcard are the boxes used for personnel moves within the site boundaries. The boxes and lids are kept in a Central Stores location in bundles of approximately 25 each. When a move is scheduled, a phone call or an electronic message is sent to the Recycle Programs Group requesting a quantity of moving boxes and lids. The requester is given enough bundles of boxes and lids to meet the requirement. The bundles are delivered by the Central Stores delivery drivers along with normal freight deliveries. No formal inventory is kept to hold down the handling costs associated with issuing specific quantities. After the move is completed, the requestor schedules the radiation monitoring/release of the boxes. When the monitoring/release is completed, the requestor flattens the boxes and lids and again bundles them in groups of 25 . The bundles are placed on the facility loading dock and the Central Stores delivery drivers return them to Central Stores to be reissued:

- Using plant forces to pick up and deliver the facility collected cardboard will increase participation in the cardboard recycling program because it becomes easier for the facility personnel to store and collect cardboard. The secret to increasing participation in any recycle program is to make it easier to recycle than it is to make the material waste. Once personnel accept the change in disposal techniques, they generally ask to be included in other recycle programs and ask for additional recycle programs.

\section{Safety}

Be aware of the safety implications when implementing any new program. Either a forklift or two people are required to load the cardboard onto a truck after it has been banded. The load can be awkward to . handle, but the weight is not a problem. Safety considerations for each type of material must be evaluated because these activities are changes from the normal routine. Safety must be the primary consideration when any change in management of a waste stream is contemplated.

\section{Recommendations}

This recycling program will reduce the volume of material going into a landfill. To implement a recycle program for cardboard, first contact vendors that are willing to recycle collected materials. Without having this up-front support mechanism in place, the volume of cardboard collected will rapidly overwhelm all but the largest storage areas. Because the material is flammable, storage of large quantities will become a safety issue and create problems that could shut down the program.

Specific questions regarding the development, implementation, or success of this program may be directed to M. L. McCollom, Manager, Recycle Programs, Westinghouse Hanford Company at (509) 376-8895. 


\section{PACKAGING REDUCTION PROJECT--"HOW-TO" RECIPE}

Title: Wood Recycling

Project Area: Recycling

\section{Purpose}

The purpose of this recycling activity is to reduce the amount of wood waste material being sent to the landfill. Wood waste is primarily scrap pallets and wooden packaging/shipping materials.

\section{Key Personnel Involved}

Manager, Recycle Programs

Material Specialist, Recycle Programs

Storekeepers, Materials Management

Truck Drivers, Materials Management

Manager, Excess, Surplus Sales and Shipping

Local Area Businesses that use pallets; Refurbishers, Pulp ar d Paper Mills

\section{Background}

Past experience at the Hanford Site has proven that there is little economic incentive for the general public to purchase excess scrap pallets and wood waste. Therefore, scrap pallets and scrap packaging/shipping containers are given away to any interested party capable of hauling them safely. This is allowed before the materials are readied for landfill disposal. The maximum amount of material hauled away has been about 3-5\% of the total annual wood waste generated. Because the reuse of these bulky products is low, many are sent to the landfill. Because it only takes 8 standard pallets to make $1 \mathrm{yd}^{3}$, the landfill cubic space requirement is high. The Central Stores operation generates approximately 10,400 recyclable pallets per year.

\section{Waste Minimization Opportunity}

A multifaceted approach to recycling wood waste has been instituted at the Hanford Site. The first step is to screen the pallets internally for possible reuse in the Central Stores or the Excess, Surplus Sales, and Shipping organizations. The next step is to allow vendors needing pallets for reuse or rebuilding, to screen for potential usable/repairable pallets. The balance of the pallets and wood scrap is then transported to a local liner board mill where the pallets are run through a large wood chipper and then over a conveyor where the metal particles are electromagnetically separated and removed. The mill uses the better quality wood pallets for feed stock in the liner board making process and the scrap wood chips are used as supplemental fuel for the "hog" feed boilers. This multifaceted approach results in virtually no wood scrap being made into waste.

\section{Benefits}

Many tangible benefits are realized by using this arrangement. Some of the 10,400 pallets and crates received with incoming freight each year at Central Stores are reused, which reduces the purchase of new pallets at an average cost of $\$ 9.00$ each. A small local business is able to rebuild and resell some of the scrap pallets while two other businesses use them for local shipments. The liner board paper mill is able to reduce the requirement for virgin tree stock and the lowest valued material in the chain is used as fuel supplement for energy recovery. The cost savings for each cubic yard of landfill space not used, because the pallets are recycled, are calculated using the current rate of $\$ 30.60$ per cubic yard. 


\section{Benefits (cont.)}

Some of the intangible benefits include improved employee morale because of resources being reused instead of thrown away. Employees are pleased to see this proactive approach to recycling on a daily basis. Another benefit is the enthusiasm this recycling activity receives when presented by the Community Ambassador Program team to local schools. This promotes public confidence that the former defense site is proactively searching for innovative ways of effectively managing waste streams.

\section{Cost Savings}

The cost savings benefit of this wood waste recycling program can be easily calculated using the data referenced previously in the text. The cost benefits have been itemized by specific activity $t, \ldots, 0$. The information is collected on a weekly average basis and multiplied by 52 to provide annual information. The annual total is divided by 8 (average number of pallets per cubic yard) to provide the total cubic yards of landfill space used per year before implementing the wood waste recycle program. Landfill disposal is $\$ 30.60 / \mathrm{yd}^{3}$.

57 pallets reused on plant per week 18 pallets reused for off-plant shipping 51 pallets reused by vendors per week 22 pallets rebuilt by vendors per week 48 pallets for liner board feed per wrek 4 pallets to private parties per week

$$
\begin{array}{ll}
57 \times 52=2,964 / 8 & =370.5 \mathrm{yd}^{3} \\
18 \times 52=936 / 8 & =117.0 \mathrm{yd}^{3} \\
51 \times 52=2,652 / 8 & =331.5 \mathrm{yd}^{3} \\
22 \times 52=1,144 / 8 & =143.0 \mathrm{yd}^{3} \\
48 \times 52=2,496 / 8 & =312.0 \mathrm{yd}^{3} \\
4 \times 52=208 / 8 & \equiv 26.0 \mathrm{yd}^{3} \\
\hline \text { Total } & 1,300.0 \mathrm{yd}^{3}
\end{array}
$$

Annual disposal costs

$1,300 \mathrm{yd}^{3} \times \$ 30.60$

Annual purchase costs

2,964 pallets $\times \$ 9.00$ each

$$
=\$ 39,780
$$$$
=\$ 26,676
$$

Total costs savings annually by recycling are $\$ 66.456$

\section{How to Implement Activity}

The implementation process requires a stepped approach. The first step is to determine the volume of the waste stream. Conversations with and estimates by several personnel in the Central Stores operation were the starting point at the Hanford Site. The information was compiled and a supportable volume of scrap was developed and compared to the original baseline information. It was determined that of the palletized/crated material passing through the Central Stores operation, 10,400 units per year were accessible for recycle.

The next step was to solicit help from various vendors regarding potential uses for the scrap being generated. The local area pallet remanufacturer has agreed to screen the scrap pallet stacks and take some for rebuilding. Two other vendors agreed to take some for reuse as shipping pallets for materials going to different locations around the local area. Although this reduced the scrap wood disposal problem, it did not deal with the final $24 \%$ that was still being sent to the landfill. A local paper liner board mill, which was already working with the Recycle Programs Group on using mixed office recycle paper in the liner board process, was queried about using wood scrap as feed stock and/or as "hog" boiler supplemental fuel. They agreed to run some tests if the material met the size and quality requirements. 


\section{How to Implement Activity (cont.)}

The Recycle Programs Group then contacted an Oregon State based company that has a large mobile wood chipper and put them in contact with the liner board mill procurement organization. The liner board mill and the wood chipper operator agreed that the machine would chip small onough to meet the liner board mills quality assurance requirements for feed stock and "hog" boiler fuel. The scrap wood is given at no cost to the vendors and the liner board mill. The vendors are responsible for any culling activity and the hauling costs. The pallets are delivered to the liner board mill scrap wood storage area and the liner board mill pays the wood chipper operator a set amount of money per "dry" unit of usable material. Government cost is reduced by avoiding the landfill costs and the hauling costs of the material hauled by the vendors. The cost of the haul to the liner board mill is roughly equivalent to the haul to the landfill. This program reduces itie arnount of wood waste which would otherwise been disposed of in the central landfill.

\section{Safety}

Safety for the Hanford Site employee, the vendor's employees, and the environment are vital for the success of this type of pre jram. A review of potential safety hazards must be conducted and the findings evaluated during the implementation process. For example, does the vendor have proper equipment to handle stacks of pallets or bulky crates without endangering the people, the equipment, or the environment. Another example of a safety evaluation would be proper loading, load securing, and unloading of this material. These types of safety items must be included in the transportation of the material to the liner board mill storage site. The most important thing is to be aware that changes in the way business is conducted may add unrecognized dangers to the process.

The best way to reduce the risk of an accident is to define the potential problems, evaluate the options, and develop a safe implementation plan before moving the first load of wood waste.

\section{Recommendations}

This program will not succeed without a proactive organization that will continue to pursue alternatives after the first series of proposals and ideas are rejected. For example, the Recycle Programs group held three meetings with the liner board mill personnel before the ideas began to blossom into something that was workable. The primary concern was finding enough vendor sources to deal with the quantities generated. This program will significantly reduce the scrap wood waste stream. At the Hanford Site, it is reducing the annual packaging waste stream total by 7.5 to $8.0 \%$.

Specific questions regarding the development, implementation, or success of this program may be directed to M. L. McCollom, Manager, Recycle Programs, Westinghouse Hanford Company at (509) 376-8895. 
WHC-MR-0448

\section{REFERENCES}

1. Browning-Ferris Industries, 1989 , "Waste Compaction Study for the Recyclery at Newby Island," San Jose, California.. 
WHC-MR-0448

This page intentionally left blank. 
WHC-MR-0448

APPENDIX A

REDUCTION OF PACKAGING WASTE PROJECT INFORMATION 
WHC-MR-0448

This page intentionally left blank. 


\section{INTRODUCTION TO PACKAGING WASTE}

Nationwide, packaging waste comprises approximately one-third of the waste being sent to solid waste landfills. This waste ranges from product and shipping containers made from plastic, glass, wood, and corrugated cardboard to packaging fillers and wraps made into a variety of plastic materials such as shrinkwrap and polystyrene peanuts.

The amount of packaging waste generated is becoming an important issue for manufacturers, retailers, and consumers. Elimination of packaging not only conserves precious landfill space, it also reduces consumption of raw materials and energy, all of which result in important economic and environmental benefits.

At the U.S. Department of Energy (DOE)-Richland Operations Office's (RL) Hanford Site, as well as other DOE sites, the generation of packaging waste has added importance. By reducing the amount of packaging waste, DOE also reduces the costs and liabilities associated with waste handling, treatment, storage, and disposal.

It is also important to note the number of increasing regulations governing packaging waste that are beginning to evolve. The Coalition of Northeast Governors, for example, has drafted model legislation that requires manufacturers and packagers to set specific measurable goals to reduce packaging waste. State of Washington retailers and manufacturers have formed an association to create voluntary packaging guidelines to hold off further regulation. In Germany, manufacturers will be held responsible for the packaging they produce, including accepting and managing packaging waste returned by the consumer.

The percentage of packaging waste within the DOE complex is similar to the national levels; thus a great opportunity exists for RL and other DOE sites to reduce the amount of packaging waste generated and disposed annually.

\section{PROJECT BACKGROUND}

This project was one of three selected by the DOE to support the implementation of Executive Order 12780, "Federal Recycling, Acquisition and Use of Environmentally Preferable Products and Services." The Order seeks to (1) study procurement practices, (2) to promote environmentally sound waste reduction, (3) to implement procurement preference programs that stimulate market demand for recycled products, and (4) promote cost-effective waste minimization.

\section{PROJECT PURPOSE}

This project investigated opportunities to reduce packaging waste through source reduction and recycling methods. Information was gathered from the Hanford Site and other DOE sites to select areas of focus that were the most applicable for implementation across the DOE complex. The investigation was conducted by Westinghouse Hanford Company (WHC) and RL, using data from all sites, with the final results and recommendations communicated DOE-wide.

\section{PROJECT SCOPE}

This project concentrated on three major areas: (1) procurement, (2) onsite distribution and packaging, and (3) recycling. Within each area, specific products or activities were targeted to determine reduction potentials. Following the recommended hierarchy for waste minimization, source reduction opportunities took precedence over recycling, volume reduction, treatment, and energy recovery. 


\section{DESCAIPTION OF METHODOLOQY}

The project was divided into four separate phases: (1)determination, (2) evaluation/study, (3) implementation, and (4) results and recommendations.

The determination phase examined the types of packaging waste DOE sites generate, which areas of study are the most important to each site, and which products offer the most potential for reduction. A baseline measurement of packaging waste generated at the Hanford Site was also developed during this phase.

The evaluation/study phase investigated ideas for reducing packaging waste and determined specifically what activities should be implemented in the next phase. The results from the latter two pliases weie assembled in an interim repolt.

In the implementation phase, packaging reduction activities were chosen for each of the three areas of the study and in nplemented on a small-scale basis at the Hanford Site. The activities chosen were (1) Vendor Participation Program, (2) Reusable Container System, (3) Shrink-wrap System--Plastic and Corrugated Cardboard Waste Reduction, (4) Cardboard Recycling, and (5) Wood Recycling.

For the final phase of the project, results and recommendations of these reduction activities were compiled into "How-to" recipes to be used at other sites in implementing similar programs. These "How-to" recipes are found at the beginning of this report and contain enough information to be used as standalone documents.

\section{RESULTS OF DETERMINATION AND EVALUATION PHASES}

\section{QUESTIONNAIRE SUMMARY}

To verify that the project scope was one that was most applicable and beneficial DOE-wide, a questionnaire was distributed to the various DOE Operations Offices, asking for their confirmation and input before project implementation. The questionnaire requested information on what kinds of packaging waste were found at other sites and in what quantities, and what waste minimization activities they are currently performing or would like to see implemented at their sites to reduce packaging waste.

Sixteen responses to the packaging questionnaire were received with all but the Oak Ridge and Savannah River Operations Offices responding. Seven of the sixteen responses were from the Albuquerque Operations Office. Some results of the packaging questionnaire are summarized below.

- Cardboard comprises the majority of packaging waste at DOE sites. Wood and plastic were second in importance with polystyrene packaging a distant third. 
- Of all the recycling programs currently in operation at DOE sites, the fewest number of those are devoted to packaging materials (see below).

Becvaling program
Office paper/newspaper
Olllubricants
Aluminum
Scrap metal ferrous/nonferrous
Cardboard/fiberboard
Wood
Plastic

\begin{tabular}{c} 
Number of sites with Program \\
\hline 15 \\
13 \\
12 \\
11 \\
7 \\
5 \\
5
\end{tabular}

- Of the total amount of solid waste disposed per year at DOE sites, five responses indicated that between 20 and $30 \%$ was packaging waste. Four responses estimated that between 10 and $20 \%$ was packaging waste.

- The major obstacles to reducing or recycling packaging material were identified as lack of resources (funding and labor), lack of an available market and remote locations hampering recycling, the attitude of employees, and radiological release issues.

- Of fourteen responses, only one site indicated that they had changed their engineering or purchasing procedures to allow the use and purchase of materials designed for recyclability, reduction, or greater recycled content.

\section{BASELINE INFORMATION}

\section{Totals}

The average amount of solid waste sent to the Central Landfill on the Hanford Site, per year for the last two years, has been $28,300 \mathrm{yd}$. Baselining efforts have determined that $36 \%$ of this is packaging waste. This amounts to approximately $10,000 \mathrm{yd}^{3}$ of packaging waste generated per year just for the Hanford Site. 


\section{BABELINE INFORMATION (cont.)}

The following table is a breakdown of the types and amounts of packaging waste generated during calendar year (CY) 1992.

\section{Waste Baseline Information}

(Total Amounts)

\begin{tabular}{llll} 
Material & $\begin{array}{l}\text { CY 1992 } \\
\text { (yd3) }\end{array}$ & $\begin{array}{l}\text { Amount Recycled } \\
\text { CY 1992 (yd3) }\end{array}$ & $\begin{array}{l}\text { Total Packaging } \\
\text { Waste (\%) }\end{array}$ \\
\hline Cardboard & 6440 & 102 & 64 \\
Plastics & 1680 & -- & 17 \\
Pallets/crates & 800 & 500 & 8 \\
Paper packing & 600 & $\ldots-$ & 6 \\
Polystyrene & 560 & $\ldots-$ & 5
\end{tabular}

This information was generated through interviews with management and employees of Central Stores operations; Site Warehousing; Solld Waste Operations; Custodial Services; and Excess, Surplus, Sales and Shipping. Further information was gathered from visual observation of warehouse, receiving, disbursing, and shipping operations, docks and dumpster locations, and from the Hanford Site Central Landfill. In addition, the "Solid Waste Landfill Volume - Waste Categories Report" and landfill operator input provided invaluable data for evaluation.

\section{Specific Contributors}

Identifying specific contributors to each packaging waste category was difficult to determine. Because no one product could be found to be a major contributor to a single waste stream, general areas of product purchase were chosen for investigation. The following is information on these product areas and the number of unit items purchased per year.

\section{Product:}

Computer systems $\quad--17,500$ packages/boxes purchased per year

Xerographic paper $\quad$-- 28,400 packages/boxes purchased per year

Janitorial supplies -- 14,400 packages/boxes purchased per year

Office supplies $\quad$-. 43,700 (estimated) packages/boxes purchased per year.

Most of these products are generally received on pallets, in boxes, and in many cases shrink-wrapped for stability. Office supplies and computer system contracts are particularly applicable to packaging reduction. All items are ordered and delivered through one vendor and therefore offer a good opportunity. Those products that are packaged in standard case lots, such as disposable coveralls and paper products are also good candidates for reduction. 


\section{PROCUREMENT SUMMARY}

Procurement was divided into two areas. The first area focused on establishing relationships between purchasers and suppliers where packaging reduction needs and opportunities could be discussed. Packaging waste reduction efforts take corporate commitment and time to make a measurable impact. The expanded use of long-term partnership arrangements, such as systems contracting, provides an optimal situation for working with vendors because of the large quantity of products that are purchased from a single supplier.

The second area looken at more aggressive procurement involvement to encourage the purchase of products that contain less packaging, greater recycled content in their packaging, or are packaged in reusable/recyclable containers. This is done during the procurement negotiation and selection process.

\section{Procurement/Vendor Participation}

The planned approach for this section is to have WHC Procurement meet with vendors and suppliers to discuss the minimization of packaging waste. The meetings will be held in a workshop setting with examples of vendor-supplied packaging waste displayed to emphasize DOE's need to reduce waste. The major focus will be on those sources that generate large volumes of packaging material. For the Hanford Site, this initial focus will be on the office supplies systems contract and computer vendors. Initial response by the vendors to this participation program has been positive.

A preliminary list of issues that will be raised with the vendors during these meetings include the following:

- Use of cardboard pallets and/or skids rather than wood

- Use of reusable totes for shipment of orders

- Use of cornstarch peanuts

- Vendor return of packaging

- Vendor delivery and installation (which would include the return of all packaging)

- Use of performance specifications rather than material specifications for shipping packages

- Encourage vendor participation in a pallet transfer programs or the return of pallets during backhaul

- Emphasize greater recycled content in product packaging or the vendor identification of recycled content in packaging for tracking purposes.

An important aspect is to provide incentives or awards to vendors to encourage their participation in the reduction of packaging waste. This not only promotes environmental stewardship, but leaves the vendors with a tangible item to promote their business. This incentive will probably take the form of a plaque or certificate from DOE recognizing their environmental awareness. 


\section{PROCUREMENT SUMMARY (cont.)}

\section{Procurement/Product Purchase}

Many waste reduction opportunities exist for the procurement process and are an important part of the project. The way a procurement and its product requirements are structured can directly affect such reductions. These opportunities are listed below.

- Dictate the requirement for the retum/recycling of packaging waste in all subcontract work.

- Use procurement preference policies in the bid process to encourage the use of recycled material in packaging ana tu yive preferunce for reduced packaging.

- Include in contracts the requirement for recycling activities at all leased facilities.

- Encourage changing from material to performance specifications for packaging requirements.

- Buy products that contain less packaging i.e., bulk.

WHC has initiated two affirmative procurement clauses stating their support for the purchase of recycled materials. The first clause, shown in Figure A-1, states that WHC supports efforts to purchase environmentally sound products and products containing recycled content. It asks suppliers whether their products are recyclable or if they contain recycled content. The second clause, shown in Figure A-2, requires information on the five categories of products for which the Environmental Protection Agency has established minimum content standards. The categories are paper products, insulation products, cement and cement products, lubricating oils, and tires. Recycled content information is required for these products. Proposals for products that do not meet the minimum content standard may be ineligible for award. 
Figure A-1

\section{general affirmative. procurement clause}

Instructions for clause (A-1, rev. 0$)$

Use: Include in all WHC solicitations that result in any materials being provided to the Hanford Site.

A-1 Recovered material/recyclable information:

Westinghouse Hanford Company (WHC) supports efforts that promote cost-effective resource conservation, recovery, and reuse. Toward that end, the acquisition cycle is viewed as an important key in understanding what is brought onto the Hanford Site as well as identifying what can be reused/recycled.

For each end product proposed to be supplied to WHC under a resultant purchase order, information as to the percent of recycled/recovered material incorporated into the end product as well as possible recycling opportunities shall be provided as set forth below:(use additional pages as necessary for additional items.)

Item No.

$\%$ Recycled/

recovered material
Recyclable

(YN) 
Figure A-2

\title{
Affirmative procurement Clause for epa guideline PROdUCts
}

\author{
Minimum recovered content requirement (A-2, rev. 0)
}

For the product(s) listed below, the percentage of recovered material listed must be included in the products proposed to Westinghouse Hanford Company (WHC) under this solicitation. Failure to propose products to these minimum levels may be grounds to consider your proposal nonresponsive and not eligible for award. Signature on the face of this solicitation specifically acknowledges compliance with this iequireritetii. it shouici ivi ivied that in conjunction with any resultant purchase order, WHC may require certifications and/or test results that verify the recovered material content.

A-2 Instructions for clause (A-2, rev. 0)

Use: Include in all WHC solicitations for the paper, insulation, cement, lubricating, or tire products listed. Include the specific product required with the associated percentage of recoverable material per the following table:

Custom clause A-2: Use A-2 to supply the applicable "product" and "percentage of recovered material." Format the clause as shown below, including headings.

\section{Product percentage recovered material}

$\begin{array}{lrlr}\text { (A) Paper products } & & \text { (B) Insulation products } & \\ \text { Newsprint } & 40 & \text { Cellulose loose-fill } & 75 \\ \text { Offset printing paper } & 50 & \text { Cellulose spray-on } & 75 \\ \text { Mimeo/duplicator paper } & 50 & \text { Perlite composition board } & 23 \\ \text { Writing paper } & 50 & \text { Rock wool } & 50 \\ \text { Office paper } & 50 & \text { Phenolic rigid foam } & 5 \\ \text { Envelopes } & 50 & \text { Glass fiber } & 6 \\ \text { Book paper } & 50 & \text { Foam in place } & 5 \\ \text { Bond paper } & 50 & \text { Rigid form products } & 9 \\ \text { Ledger paper } & 50 & & \\ \text { Cover stock } & 50 & \text { (C) Cement and cement products } & \\ \text { Toilet tissue } & 20 & \text { Product content of fly ash } & 15 \\ \text { Paper towels } & 40 & & \\ \text { Paper napkins } & 30 & & \\ \text { Facial tissue } & 5 & \text { (D) Lubricating oils } & \\ \text { Paper dollies } & 40 & \text { Product content of re-refined } & 25 \\ \text { Corrugated pkg boxes } & 35 & & \\ \text { Fiber packaging boxes } & 35 & \text { (E) Tires } & \\ \text { Paperboard cartons } & 80 & \text { Must first consider retreads for all } & \\ \text { Paperboard pad backing } & 90 & \text { applications. } & \end{array}$




\section{ONSITE DISTRIBUTION AND PACKAGING SUMMARY}

The Central Stores or onsite distribution and packaging process was investigated to determine if the methods used to fill store stock orders could be improved to reduce waste. Central Stores on DOE sites are similar to retail stores filling orders from in-stock supplies. The orders are repackaged according to requested quantity and shipped to individual facilities. One of the most workable methods to reduce the volume of packaging waste going to the landfill is to capture as much as practical following receipt at a Central Stores or a centralized location before disbursing packages to the field. Virtually all packaging waste sent to the field eventually becomes landfill waste.

The following discusses waste minimization ideas generated for the reduction of packaging waste during onsite distribution and packaging operations. Following the description of each idea is an evaluation. The ideas are categorized by type of packaging waste and it is noted where an idea may affect more than one waste stream.

\section{Cardboard}

- Capture packaging waste at Central Stores or at a centralized location through the use of reusable containers. (See "How-to" recipe on Reusable Container Systems for implementation information.)

This involved unpacking certain boxed commodities, repacking them into reusable totes for delivery to the field, and subsequently staging the accumulated cardboard for recycling. These containers could be plastic totes, collapsible bags, or laundry carts that pull together orders or move supplies within an office building. The empty totes would be returned to the Central Stores storage location using the regular stores delivery trucks.

Possibie candidates for small-scale tests of reusable containers include items such as launderable towels, radiation protective clothing, office supplies, select janitorial items, and other low-cost, nonbreakable items. Xerographic paper, which is purchased in large quantity on the Hanford Site, is not a good candidate for this program. Its corrugated container is already designed to have a reduced volume.

According to Drs. Selke and Twede; of the Michigan State University School of Packaging, a returnable container system is most beneficial in a closed-loop system. Many of the problems associated with returnable containers are the expense of tracking the containers, purchasing costs for the containers and their loss or theft, and the cost of backhaul. On a DOE site, many of these issues are mitigated with a closed-loop system that would minimize loss and with the backhaul of containers on a return trip to the Central Stores warehouse or a centralized distribution center.

- Use a lightweight "doughnut" box or tray in the shrink-wrap machine. (See the "How-to" recipe on Shrink-wrap Systems--Plastic and Corrugated Cardboard Waste Reduction for implementation information.)

Corrugated cardboard boxes are usually filled with Store orders and are shrink-wrapped for onsite distribution. The purpose of a box in the shrink-wrap machine is to contain the items being wrapped and to give the shrink-wrap a form to mold around without sticking to the material being shipped. A large volume reduction opportunity exists with the use of a lighter weight box to fill these orders. The corrugated cardboard would then remain in a centralized area ready for recycle. 
- Use moving racks and shelves to transport onsite orders.

During a move certain items are not packed, but are placed on moving racks or shelves to be transferred. This same option could be applied to shipment of new items or Central Stores orders from the warehouse. This would encourage both the reduction and the recycling of cardboard.

\section{Wood}

- Use cardboard pallets and skids to replace wood.

Heavy-duty corrugated cardboard pallets have been purchased-ftin GATE Paliel Systenis, Crown Point, Indiana to test and evaluate onsite at Central Stores and several satellite warehouses. The pallets are durable, lightweight, splinterless, recyclable, and have a 2,800 pound capacity. One of the benefits of cardboard pallets is the reduced weight of freight shipped and the consequent reduction in fuel consumption and pollutant releases. Limited application is expected, however, as these pallets are generally not suitable for prolonged outdoor use or outdoor storage and cannot handle the loads required.

\section{Plastic}

- Upgrade existing shrink-wrap machine to one that adjusts to the size of the box and is more energy efficient.

The consensus was that the existing semiautomated Great Lakes system was appropriate for the type of wrapping presently required for onsite packaging and shipping, so this idea was rejected.

- Replace current shrink-wrap material with a thinner plastic. (See "How-to" recipe on Shrinkwrap Systems--Plastic and Corrugated Cardboard Waste Reduction.)

A plastic volume reduction is being sought through the testing of thinner polyethylene shrink-wrap material. The performance test involved substituting thinner poly sheeting (1.0 to $1.5 \mathrm{mil}$ ) in place of the 2.0-mil material currently being used. Changing to the thinner material, if proven satisfactory, can render a reduction of 25 to $50 \%$ in plastic waste from the disbursing operations.

Similarly, Janitorial services are evaluating a reduction in the currently used 2-mil poly trashcan liners. In addition, and primarily because of the sitewide office paper recycling program, the frequency for emptying and/or changing out waste basket poly liners has been changed from daily to an as needed basis. Preliminary estimates are that a reduction of up to $75 \%$ poly waste is possible under such an arrangement.

- Replace shrink-wrapping with the use of plastic stretch wrap.

A second type of wrapping material used is stretch wrap which, unlike shrink-wrap requires no heat source to provide a good seal. Stretch wrap can be used on some small items and is used for stabilizing palletized materials for both onsite and offsite shipping. While both materials are recyclable, a viable avenue for doing so has not yet been established. 


\section{Polystyrene}

- Substitute cornstarch packing material for polystyrene.

Cornstarch "peanuts" and other packing material are a biodegradable product made of $95 \%$ cornstarch and $5 \%$ inert materials that when wetted down with water dissolve readily into a nonregulated substance. Cornstarch peanuts are currently used on the Hanford Site when supplementary quantities of protective packing "peanuts" are required.

It might be beneficial to replace all polystyrene packing material sent out to a site with a cornstarch substitute, especially when polystyrene reuse usually occurs only once before landfill disposal. A better option might be to replace the pulystyrene and look for a local recycler or shipping company to take the collected amount.

\section{RECYCLING}

The third area focused on studying recycling programs for packaging waste. Although it was not feasible in the given project time frame to institute an encompassing recycling program at one site, specific recycling opportunities for sitewide corrugated cardboard and wood waste have been investigated and implemented on a small-scale test basis.

The following discusses waste minimization ideas generated for the recycling of packaging waste. Following the description of each idea is an evaluation of that idea and an account of why or why it will not be implemented in the next phase. The ideas are categorized by type of packaging waste and it is noted where an idea may affect more than one waste stream.

\section{Cardboard}

- Implement a sitewide recycling program. (See "How-to" recipe on Cardboard Recycling for implementation information.)

Cardboard recycling offers, by far, the greatest opportunity to reduce packaging waste going to our landfills. Accumulating recyclable cardboard at the many field locations and arranging for subsequent pickup and transportation to a centralized staging area will be implemented in the following fiscal year. The logistics and various barriers to cardboard recycling were too many to implement a sitewide program in the three months allotted in the project. A progress report on success with the sitewide cardboard recycling program will be submitted as an addendum to this report ir: fall 1994.

The single largest deterrent to collecting cardboard from the rest of the Hanford Site facilities is radiation monitoring concerns. Important issues for implementing an onsite cardboard recycling program include deciding (1) how the cardboard will be collected and returned to a central location, (2) the necessary labor and equipment required to process the cardboard (i.e., baler), (3) the storage of cardboard at site facilities in nonradiologically controlled areas, and (4) the certification for release that this material has not been in an radiologically contaminated area. 
Current cardboard recycling activities at the Hanford Site involve cardboard boxes being reused at Central Stores for onsite shipping or broken down, stacked on surplus pallets, then banded for pickup by a local recycling contractor. In addition, almost $100 \%$ of the cardboard shipped with fumiture is captured at Central Stores for recycling and the moving box recycling program has eliminated a large quantity of new moving boxes being purchased. (This information is included in the "How-to" recipe on Cardboard Recycling at the front of this report.)

- Reuse corrugated containers for the packaging and distribution of Central Stores or site material.

- WHC and many of the other DOE sites currently follow this practice, but at best these boxes are only reused once and almost $100 \%$ of the time end up in the site landfill.

- Purchase and use a compactor/baler.

The use of a compactor/baler was reviewed during this study. It was determined that for WHC application, the labor required to use the baler would be $5 \%$ greater than the present method of strapping the collapsed boxes to a scrap pallet. Furthermore, there would be purchase price and installation costs of approximately $\$ 17,500$. The annual maintenance costs are undefined; however, experience suggests 5 to $7.5 \%$ per year based on purchase price. The palletized and banded material is currently loaded on vendor trucks and transported for recycle about every 15 working days. The projections of anticipated growth of the cardboard recycle program at Central Stores will require the vendor to pick up once per week to reduce the fire hazard potential. Notwithstanding, periodic reviews of the cost effectiveness and the attributes of a compactor/baler will be performed.

\section{Wood}

The Wood Recycling Program was detailed this summer and will be implemented sitewide in fiscal year 1994. The Wood Recycling Program is described in a "How-to" recipe at the front of the report and contains information on several of the following ideas. In particular, the wood program will use the services of the pulp and paper mill, pallet refurbishing companies, and businesses that can reuse WHC wood pallets and will take them for free. A progress report on the success of the Wood Recycling Program will be completed in fall 1994 and included as an addendum to this report. It will discuss efforts to educate and encourage the local community to adopt a similar wood recycling program.

- Join a pallet transfer pronram. (See "How-to" recipe on Wood Recycling for more information on implementation.)

Many companies who ship material use wood pallets. A pallet transfer program is a means of selling or giving excess wood pallets to someone who can reuse them. The Hanford Site currently gives pallets to a local block ice distribution company and also occasionally sends off a truckload of excess pallets with the office supplies system contractor who will reuse them in their operations. This is an important option to explore.

- Use wood waste as a feedstock in paper mill operations. (See "How-to" recipe on Wood Recycling for more information.) 
Discussions have been held with a local/regional wood pulp plant (Boise Cascade, Wallula, Washington) with the possibility of all surplus pallets being used as feed stock for liner board production. Other applications may include using some of the scrap wood for hog boiler feed that supplements their plant steam requirements.

The added benefit to this option is that there are several other businesses within the Tri-Cities community and at the Hanford Site that have large quantities of wood waste. A good opportunity exists to form partnerships with these companies and possibly other local area businesses to reuse wood waste in an energy recovery process.

- Use a wood chipper.

A wood shredder was acquired for onsite use and is presently in the testing stage.

However, early indications show that one pass through the shredder merely breaks up the pallets into relatively large pieces suitable only for lowering the volume/mass for landfilling or possibly being used as a hog boiler feed mentioned above. The use of a chipper instead of a shredder would make the material more easily marketable.

The chips can be used as landscape "bark" or as a medium that can be mixed with sewage sludge to form a fertilizer seal over newly planted ground in nonpopulated areas. The wood chips could also generate compost material for onsite use.

Chippers, from pulp and paper mills are available in the Northwest for about $\$ 175$ /hour and will come to a location if the pallet quantity is sufficient to keep the machine busy for a full day. They can consume from 400 to 600 pallets per hour. An offset to this cost is the chipped wood byproduct. Locally, the bone dry units (BDUs) are marketable for $\$ 18.00$ to $\$ 22.00$ each $(2,400$ pounds of dry wood chips equals one BDU). It will require an average of 60 to 70 pallets to create one BDU.

- Refurbish wood pallets. (See "How-to" recipe on Wood Recycling at the front of this report.)

Another proposal under consideration is from a small, local, minority-owned business (Tri-City Pallets, Pasco, Washington). They are involved in pallet collection, repairing as necessary, and acting as a pallet broker for other users. This proposal is geared more toward the usable/fixable standard-sized pallets but would include some of the nonstandard sizes if the pailet supply could be accurately forecast.

- Burn excess wood pallets.

This is not the most environmentally sound option and is no longer allowed on the Hanford Site. 


\section{Plastic}

- Recycle plastic stretch wrap and shrink-wrap.

While both materials are recyclable, an avenue for doing so has not yet been established. Some retail department stores such as Sears, Target, and Nordstrom, however, are involved in pollution prevention activities and may be willing to join forces in recycling. Recycling programs for many plastics do not exist locally, but joining forces with a regional chain may provide access to greater recycling opportunities.

\section{Polystyrene}

- Polystyrene packing material offers great opportunity for reuse/recycle. Approximately $75 \%$ of the polystyrene packing "peanut" accumulations at the Central Stores receiving area have historically been reused for packaging onsite disbursements and the excess, surplus sales, and shipping operation for packaging on and offsite shipments. It can be reasonably assumed, however, that following second use, most all reused packing would become landfilled packaging waste.

Another viable option is to recycle the material through the polystyrene industry. They are heavily promoting the recyclability of their material. At present in the United States approximately $12 \%$ of polystyrene is recycled, but European countries have recycled close to 60 to $80 \%$ of this material. United States industry has established nationwide polystyrene recycling dropoff locations. While opportunities are sometimes found, which allow the reuse or recycle of the polystyrene materials, efforts to locate a more permanent recycling outlet for the Hanford Site are continuing. It may be possible to negotiate a contract with a closed-loop. user of polystyrene in the Portland, Oregon area. This user recycles the "peanuts" to local Portland-area manufacturers for use in packaging their products. They are then collected and redistributed again to the manufacturing community. It is our expectation that once such an arrangement can be completed, all shipments made, both onsite and offsite, requiring protective packing will be packaged with the $100 \%$ biodegradable packing materials referenced earlier. The volume of landfilled polystyrene "peanuts" would be reduced by an estimated 70 to $75 \%$.

Changes in the operating procedures in any of these three areas also require examining the associated labor and expenses involved, adjusting warehouse or storage configurations, and revising policies and procedures. 


\section{CONCLUSIONS AND RECOMMENDATIONS}

Both the Hanford Site baselining effort and the DOE-wide questionnaire identified the major packaging wastes, in order of magnitude, as corrugated cardboard, plastic, and wood. Neither of the above, however, could identify single, significant products that are major contributors to any of the waste streams. In lieu of finding specific products, the project identified waste minimization methods that focus on reducing one or more of the three waste streams. The packaging waste baseline has also confirmed that the solid waste generated throughout the DOE complex contains approximately the same $30 \%$ packaging waste materials as national industry.

It is important to note that questionnaire respondents, for the most part, believe that packaging waste does not comprise a majority of their solid waste and that the predom nantly identified means of reducing this waste focus on recycling. It is difficult for any consumer or purchaser to believe that they can minimize packaging waste through source reduction. This project has determined that there are a number of viable source reduction alternatives for reducing packaging waste available to large consumers such as DOE and its contractors. As a customer, the DOE community is in an excellent position to form working relationships with their suppliers to discuss packaging reduction needs.

The "How-to" recipes for each area of the project describe different means of reducing packaging waste generated within DOE. If $30 \%$ were reduced, it would result in an approximate cost savings of between $\$ 2$ and $\$ 6$ million per year. Sanitary waste and packaging waste, specifically, are not necessarily the most important waste stream to DOE sites and facilities; however, this project has shown that for a little effort in the right areas a large amount of waste can be eliminated for a sizable cost savings. 
WHC-MR-0448

This page intentionally left blank.

A-16 
WHC-MR-0448

\section{APPENDIX B}

REDUCTION IN PACKAGING WASTE COBT SAVINGS CALCULATIONS

B-i 
WHC-MR-0448

This page intentionally left blank.

B-ii 


\section{COST SAVINGS FOR U.S. DEPARTMENT OF ENERGY}

This information is based on the U.S. Department of Energy, Office of Environmental Managment, Waste Minimization Division (EM-334) "Waste Cost Avoidance Model" (April 1994), and the "Annual Report on Waste Generation and Waste Minimization Progress, 1991-1992" (February 1994).

According to the "Annual Report on Waste Generation and Waste Minimization," the total amount of Sanitary waste dlsposed by U.S. Department of Energy (DOE) sites in 1992 was approximately 90,000 metric tons. Based on Hanford Site packaging waste baselining efforts, and similar national estimates for industry, one-third of this waste is produced from packaging materials. That amounts to a total of 30,000 metric tons of packaging waste generated per year.

The "Waste Cost Avoidance Model" can be used to calculate a cost savings for amounts of packaging waste reduced. The "Waste Cost Avoidance Model" provides a rough estimate of varying costs across the nation for handling and disposing of sanitary waste, and can be used to determine a rough cost savings for the entire DOE complex.

If an estimated $30 \%$ of packaging waste is reduced across DOE, the following cost savings can be realized using the cost per ton for sanitary waste disposal at the Hanford Site, at the highest cost site, and at the median value site.

Definition: $\quad$ Tonne $=$ one metric ton $=1000$ kilograms

Ton $=$ one english ton $=2000$ pounds

TOTAL AMOUNT OF PACKAGING WASTE, DOE-WIDE $\quad 30,000$ tonnes

(33.069 tons)

A $30 \%$ REDUCTION IN THIS QUANTITY EQUALS $\quad 9,000$ tonnes

Cost per ton for Disposal:

( 9,921 tons)

Hanford Site $=\$ 196.00$ (only one site was lower in cost than the Hanford Site)

Highest cost site $=\$ 886.64$

Median value site $=\$ 655.80$

\section{Cost Savings}

Hanford Site

High value

Median value

$\$ 196.00 /$ ton $\times 9,921$ tons $=\$ 1.94$ million/year

$\$ 886.64 /$ ton $\times 9,921$ tons $=\$ 8.90$ million/year

$\$ 655.80 /$ ton $\times 9,921$ tons $=\$ 6.50$ million $/$ year

The sanitary waste disposal costs for the Department of Energy are significantly higher than those for private industry and the general public. This is due to the lower volume of waste that the DOE processes per their fixed operating costs. A low volume with average to high operating costs will drive up the cost per ton for DOE disposal. Conversely, however, difficulties related to siting, operating, closing, and constructing new landfills at DOE sites will inhibit their use and provide incentive for the DOE to use offsite landfills in their local communities.

With all of these costs and considerations taken into account a conservative estimate shows that between $\$ 2.0$ and $\$ 6.0$ million dollars can be saved per year by reducing the amount of packaging waste disposed within the DOE by $30 \%$. 
WHC-MR-0448

This page intentionally left blank.

B-2 


\section{DISTRIBUTION}

Number of copies

\section{OFFSITE}

26

\section{U.S. Department of Eneray}

B. Bennington

U.S. Department of Energy

Waste Isolation Pilot Plant

Jal Highway

Carlsbad, NM 88220

L. Bingham

U.S. Department of Energy - Idaho Operations Office 785 DOE Place

Idaho Falls, ID 83402 **POUCH**

K. Catlett

U.S. Department of Energy - Oak Ridge Operations Office 200 Administration Road

Federal Building

Oak Ridge, TN 37830 "*POUCH"*

A. Colarusso

U.S. Department of Energy - Nevada Operations Office $2765 \mathrm{~S}$. Highland Avenue

Las Vegas, NV 89193-8518 "*OUCH"*

O. Critchfield

U.S. Department of Energy - Albuquerque Operations Office

P.O. Box 5400

Albuquerque, NM 87185-5400 **POUCH"*

M. Dionisio

EM-552

Trevion II, 404

U.S. Department of Energy

Germantown, MD 20874

\section{A. Edelman}

ER-8.2

GTN, G-417

U.S. Department of Energy

Germantown, MD 20585

R. Fleming

EM-431

Trevion II, 206

U.S. Department of Energy

Germantown, MD 20874

Distr-1 
DISTRIBUTION (cont.)

Number of copies

\section{OEFSITE}

U.S. Department of Eneray (cont.)

J. Hancock

EM-334

Trevion II, 437

U.S. Department of Energy

Germantown, MD 20874

J. Imam

RW-33

Forrestal, 7F-070

U.S. Department of Energy

Washington, D.C. 20585

K. King

U.S. Department of Energy - Oakland Operations Office 7000 East Avenue, P.O. Box 808

MS-L-574

Livermore, CA 94550 **POUCH**

G. Klipa

EM-323

Trevion II, 345

U.S. Department of Energy

Germantown, MD 20874

R. Lang

U.S. Department of Energy - Chicago Operations Office 9800 South Cass Avenue

Bldg. 201

Argonne, IL 60439 **POUCH**

J. Lum

EM-334

Trevion II, 437

U.S. Department of Energy

Germantown, MD 20874

J. Marchetti

DP-64

GTN, C-406

U.S. Department of Energy

Germantown, MD 20585 


\section{DISTRIBUTION (cont.)}

\section{Number of coples}

\section{OFFSITE}

\section{U.S. Department of Energy (cont.)}

M. Miles

U.S. Department of Energy - Savannah River Operations Office P.O. Box A

Aiken, SC 29808 *"POUCH"*

S. Miller

GC-11

Forrestal, 6A-113

U.S. Department of Energy

Washington, D.C. 20585

J. Powers,

EH-231

Forrestal, 7A-085

U.S. Department of Energy

Washington, D.C. 20585

B. Prymak

U.S. Department of Energy - Rocky Flats Operations Office

Bldg. 116

Golden, CO 80402 **POUCH"*

B. Redeker

U.S. Department of Energy

Bonneville Power Adminstration

P.O. Box 3621 - AJ

Portland, OR 97208

R. Sharma

NE-47

GTN, F-416A

U.S. Department of Energy

Germantown, MD 20585
J. Short
EM-334
Trevion II, 437
U.S. Department of Energy
Germantown, MD 20874 
WHC-MR-0448

\section{DISTRIBUTION (cont.)}

\section{Number of coples}

\section{QFFSITE}

\section{U.S. Department of Energy (cont.)}

B. Shroff

U.S. Department of Energy - Fernald Operations Office

P.O. Box 398705

Cincinnati, $\mathrm{OH} 45239-8705$ **POUCH**

R. Smith

EM-62

Forrestal, 3G-063

U.S. Department of Energy

Washington, D.C. 20585

T. Tyborowski

CR-145

Forrestal, 4A-178

U.S. Department of Energy

Washington, D.C. 20585

D. Walter

EE-22

Forrestal, 5G-067

U.S. Department of Energy

Washington, D.C. 20585

1

C. Dutro

REECO

3271 S. Highland Ave. \#702

P.O. Box 98521

Las Vegas, NV 89193-8521

1

P. Cannon

EG\&G - Idaho National Engineering Laboratory

P.O. Box 1625

Idaho Falls, ID 83415

1

A. Johnson-Duarte

Sandia National Laboratory

7011 East Avenue

Livermore, CA 94550

1

H. Noskin

Los Alamos National Laboratory

MS-K572

P.O. Box 1663

Los Alamos, NM 87545

Distr-4 


\section{DISTRIBUTION (cont.)}

\section{Number of ceples}

\section{OFFSITE}

1

1

\section{ONSITE}

4
B. Schlosberg

Allied Signal, Inc., Kansas City Division

D/922, SC-8

P.O. Box 419159

Kansas City, MO 64141-6159

J. Thuot Argonne National Laboratory - East 9700 South Cass

Argonne, IL 60439
A5-15

A5-15

A5-15

A $1-65$
B2-35

G1-40

G1-56

G1-40

B2-22

G7-22

G1-56

G1-56

B2-22

L8-04

L8-15

H4-17 
WHC-MR-0448

This page left intentionally blank.

D 

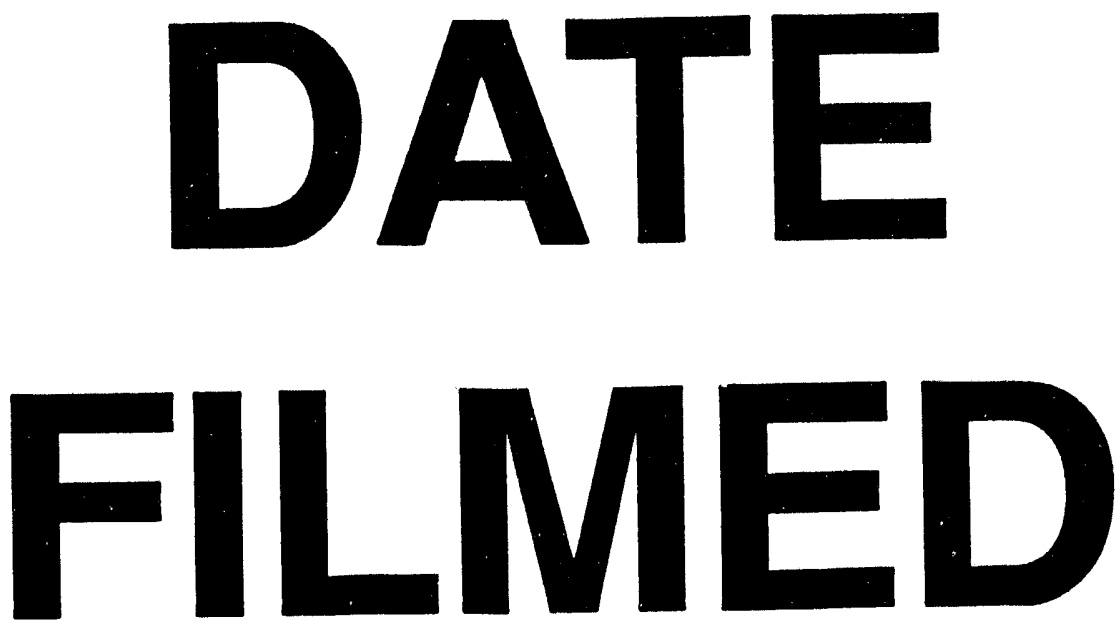

$9 / 13 / 94$
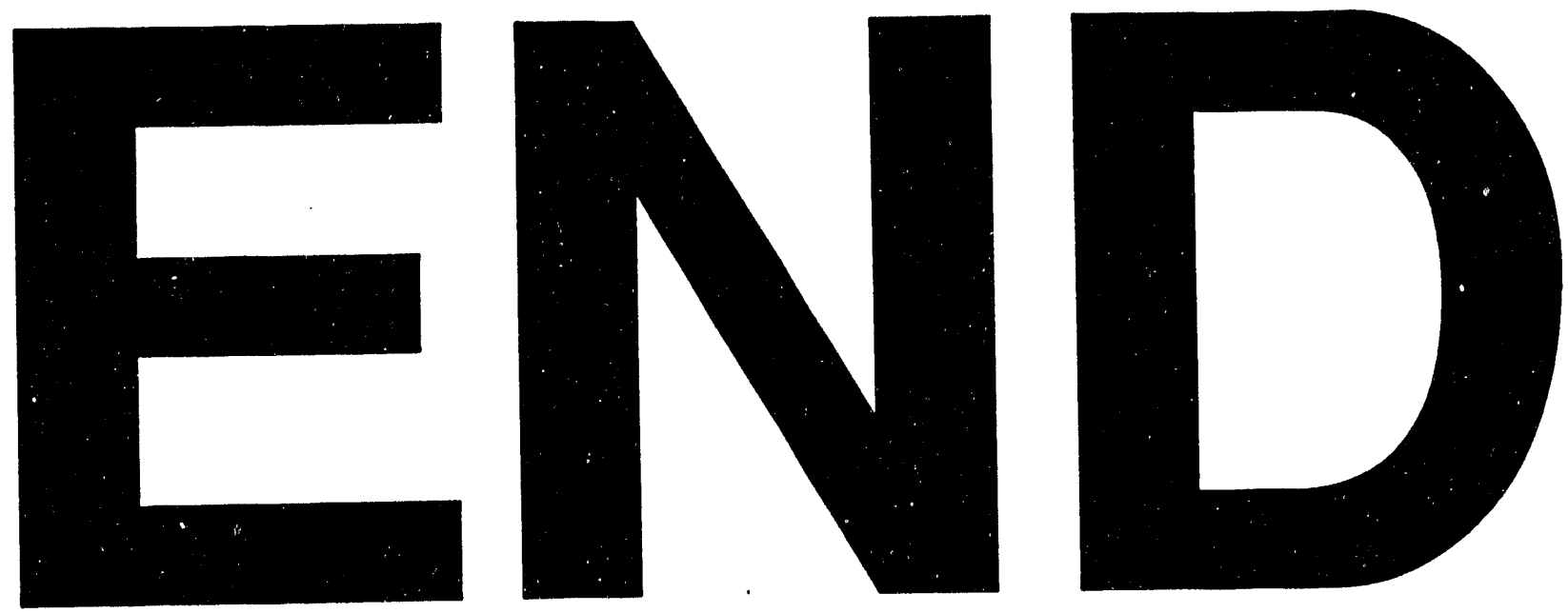


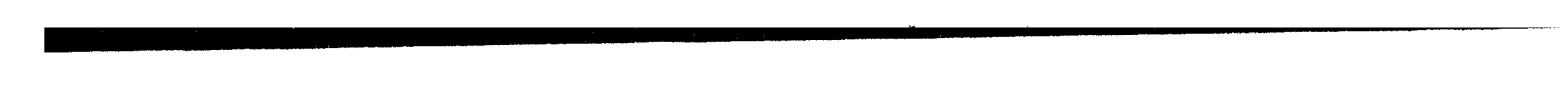

$\emptyset$ 